\title{
Contribution of feldspar and marine organic aerosols to global ice nucleating particle concentrations
}

\author{
Jesús Vergara-Temprado ${ }^{1}$, Benjamin J. Murray ${ }^{1}$, Theodore W. Wilson ${ }^{1}$, Daniel O'Sullivan ${ }^{1}$, Jo Browse ${ }^{1,2}$, \\ Kirsty J. Pringle ${ }^{1}$, Karin Ardon-Dryer ${ }^{3}$, Allan K. Bertram ${ }^{4}$, Susannah M. Burrows ${ }^{5}$, Darius Ceburnis ${ }^{6}$, \\ Paul J. DeMott ${ }^{7}$, Ryan H. Mason ${ }^{4}$, Colin D. O'Dowd ${ }^{6}$, Matteo Rinaldi ${ }^{8}$, and Ken S. Carslaw ${ }^{1}$ \\ ${ }^{1}$ Institute for Climate and Atmospheric Science, School of Earth and Environment, University of Leeds, \\ Woodhouse Lane, Leeds, LS2 9JT, UK \\ ${ }^{2}$ College of Life and Environmental Sciences, University of Exeter, Penryn, TR10 9EZ, UK \\ ${ }^{3}$ Department of System Biology, Harvard University, Harvard Medical School, Boston, USA \\ ${ }^{4}$ Department of Chemistry, University of British Columbia, Vancouver, BC, V6T1Z1, Canada \\ ${ }^{5}$ Pacific Northwest National Laboratory, Atmospheric Sciences and Global Change Division, \\ P.O. Box 999 MS K-24, Richland, WA 99352, USA \\ ${ }^{6}$ School of Physics and Centre for Climate and Air Pollution Studies, Ryan Institute, National University \\ of Ireland Galway, Galway, Ireland \\ ${ }^{7}$ Department of Atmospheric Science, Colorado State University, Fort Collins, CO 80523-1371, USA \\ ${ }^{8}$ Italian National Research Council (CNR), Institute of Environmental Sciences and Climate (ISAC), \\ via P. Gobetti 101, 40129 Bologna, Italy
}

Correspondence to: Jesús Vergara-Temprado (eejvt@leeds.ac.uk)

Received: 14 September 2016 - Discussion started: 21 September 2016

Revised: 16 February 2017 - Accepted: 1 March 2017 - Published: 15 March 2017

\begin{abstract}
Ice-nucleating particles (INPs) are known to affect the amount of ice in mixed-phase clouds, thereby influencing many of their properties. The atmospheric INP concentration changes by orders of magnitude from terrestrial to marine environments, which typically contain much lower concentrations. Many modelling studies use parameterizations for heterogeneous ice nucleation and cloud ice processes that do not account for this difference because they were developed based on INP measurements made predominantly in terrestrial environments without considering the aerosol composition. Errors in the assumed INP concentration will influence the simulated amount of ice in mixed-phase clouds, leading to errors in top-of-atmosphere radiative flux and ultimately the climate sensitivity of the model. Here we develop a global model of INP concentrations relevant for mixed-phase clouds based on laboratory and field measurements of ice nucleation by K-feldspar (an ice-active component of desert dust) and marine organic aerosols (from sea spray). The simulated global distribution of INP concentrations based on these two species agrees much better with currently available ambient
\end{abstract}

measurements than when INP concentrations are assumed to depend only on temperature or particle size. Underestimation of INP concentrations in some terrestrial locations may be due to the neglect of INPs from other terrestrial sources. Our model indicates that, on a monthly average basis, desert dusts dominate the contribution to the INP population over much of the world, but marine organics become increasingly important over remote oceans and they dominate over the Southern Ocean. However, day-to-day variability is important. Because desert dust aerosol tends to be sporadic, marine organic aerosols dominate the INP population on many days per month over much of the mid- and high-latitude Northern Hemisphere. This study advances our understanding of which aerosol species need to be included in order to adequately describe the global and regional distribution of INPs in models, which will guide ice nucleation researchers on where to focus future laboratory and field work. 


\section{Introduction}

In the absence of aerosol particles which can act as icenucleating particles (INPs), liquid water droplets can supercool to temperatures below $-37^{\circ} \mathrm{C}$ (Riechers et al., 2013; Herbert et al., 2015). It is well-known that ice formation frequently occurs at much higher temperatures in many clouds, indicating that INPs are prevalent in the atmosphere (Choi et al., 2010; Rosenfeld et al., 2011). In supercooled and mixed-phase clouds (containing ice and water) INPs cause clouds to glaciate, which leads to changes in many cloud properties such as cloud lifetime, their radiative effect on the atmosphere, and the formation of precipitation through the Wegener-Bergeron-Findeisen process (Murphy and Koop, 2005; Korolev, 2007) and possibly cloud ice multiplication processes (Hallett and Mossop, 1974). In the mixed-phase cloud regime, the dominant freezing mechanism is thought to be through INPs that are immersed within cloud droplets, known as immersion freezing (Westbrook and Illingworth, 2011; Field et al., 2012; Murray et al., 2012). Hence, this is the pathway we focus on in this study.

Heterogeneous freezing in climate models and operational numerical weather prediction models is usually based on parameterizations that depend on the temperature (Young, 1974; Meyers et al., 1992) or the size distribution of aerosol particles as well as the temperature (DeMott et al., 2010). These parameterizations treat aerosol particles all around the globe and across seasons as having the same ice-nucleating properties irrespective of the aerosol chemical composition. This is an unrealistic assumption that may affect the realism of mixed-phase clouds in models.

Over the Southern Ocean clouds tend to persist in a supercooled state more commonly than models predict (BodasSalcedo et al., 2014), which might be related to the very low INP concentrations that exist in this region but are not simulated in models (Bigg, 1973; DeMott et al., 2016). It has been shown that fewer INPs in the Southern Ocean lead to less ice and more supercooled water in model clouds, with a significant impact on the radiative properties of the clouds (Tan et al., 2016). The variability between different models in the representation of cloud glaciation can lead to differences of tens of degrees in the temperature at which clouds glaciate (McCoy et al., 2015). A better representation of mixed-phase clouds in climate models is important for climate prediction. For example, Tan et al. (2016) concluded that the response of global mean surface temperature to a doubling of $\mathrm{CO}_{2}$ is more than one degree greater when mixed-phase clouds are better represented. This cloud-phase feedback is particularly sensitive to the amount of supercooled liquid in Southern Ocean mixed-phase clouds while most current models are biased relative to measurements (McCoy et al., 2015).

In the future, regional and global climate models will include improved representations of cloud processes (Bauer et al., 2015), including ice processes, so an improved representation of heterogeneous ice nucleation will be required to make the models more physically realistic and correct some of the main biases. In particular, studies have shown that clouds are sensitive to INP concentrations, which could affect the radiative balance of the atmosphere (Zeng et al., 2009; Hoose et al., 2010b; DeMott et al., 2010; Wang et al., 2014; Tan et al., 2016). The reliability of such studies will depend on being able to relate the changes in cloud properties to emitted aerosol species so that we can attribute future changes in weather and climate to particular aerosol sources. Global aerosol models have, for many years, been based on transported aerosol species from different sources, which enables aerosol radiative forcing to be related to anthropogenic and natural emissions and their effects on cloud droplet formation (Ghan and Schwartz, 2007; Rap et al., 2013; Carslaw et al., 2013; Kodros et al., 2015). Our ability to achieve the same level of realism for ice formation has been much more difficult to achieve, partly because it has been challenging to identify species-specific ice-nucleating properties (Hoose and Möhler, 2012; Murray et al., 2012) and model them on a global scale.

Previous studies have simulated heterogeneous ice nucleation on a global scale accounting for different aerosol species (Lohmann and Diehl, 2006; Hoose et al., 2010b, a; Sesartic et al., 2013; Spracklen and Heald, 2014). These studies used classical nucleation theory to calculate nucleation rates using contact angles derived from laboratory data for each INP species. This approach has the advantage that the time dependence of ice nucleation is represented (although temperature is the main driver of nucleation), but when a single contact angle is used to describe ice nucleation by a single aerosol species, particle-to-particle variability is not represented (Herbert et al., 2014) as long-time integration will eventually allow all particles to nucleate ice.

Classical nucleation theory can be extended with a distribution of contact angles to account for differences in the icenucleating ability between different particles within the same material (Marcolli et al., 2007; Eidhammer et al., 2009; Niedermeier et al., 2011; Broadley et al., 2012; Herbert et al., 2014) and has been applied in models (Wang et al., 2014). In addition, it has been shown that representation of the time evolution of the distribution of contact angles is necessary to improve the representation of ice formation in a cloudresolving model under some conditions using classical nucleation theory (Savre and Ekman, 2015).

The alternative to describing ice nucleation by classical nucleation theory is to use a singular approximation (Vali et al., 2015) in which the time dependence of nucleation is assumed to be of secondary importance compared to the particle-to-particle variability (just a fraction of particles nucleates ice). This approach has been used to define the population of INPs in previous model studies (Niemand et al., 2012; Atkinson et al., 2013; Wilson et al., 2015).

The ice-nucleating efficiency using the singular description is defined by a temperature-dependent density (i.e. per unit surface area) of active sites, $\left(n_{\mathrm{S}}(T)\right)$ which represents a 
spectrum of active sites with variable characteristic ice nucleation temperatures. The temperature-dependent number of active sites per surface area can also be normalized to another parameter characteristic of the aerosol population (such as mass or volume; Murray et al., 2012). From this density of active sites, one can calculate what fraction of the particles will nucleate ice at a certain temperature (See Appendix B). In the case of having different aerosol species, a different density of active sites for every species has to be defined in order to account for their different abilities in nucleating ice.

The singular description of ice nucleation is consistent with many laboratory studies showing that particle-toparticle variability is the main factor driving the measured spectrum of INP concentrations with temperature (Vali, 2008; Herbert et al., 2014; Vali and Snider, 2015) for most of the known atmospherically relevant ice-nucleating species. However, it should be borne in mind that time dependence could play a role in long-lived stable mixed-phase clouds where ice crystals are produced over a long period of time (Morrison et al., 2011; Murray et al., 2011; Westbrook and Illingworth, 2013; Herbert et al., 2014). Nevertheless, the singular approach for ice nucleation can be used to approximate INP concentrations, which can be calculated with knowledge of the number, size distribution and density of active sites of the relevant INP species.

Mineral dust is considered to be the dominant icenucleating species in many parts of the world (Hoose et al., 2010b; Ardon-Dryer and Levin, 2014; DeMott et al., 2015; Boose et al., 2016). Satellite measurements have shown a negative correlation between the amount of supercooled water and dust concentration (Choi et al., 2010), suggesting that dust is important for cloud glaciation. The ice-nucleating ability of dust has been quantified in several studies (Koehler et al., 2010; Niemand et al., 2012; Broadley et al., 2012; Augustin-Bauditz et al., 2014). Atkinson et al. (2013) found that K-feldspars are far more effective at nucleating ice than any of the other minerals in desert dust, which is supported by several later studies (Wex et al., 2014; Harrison et al., 2016; Zolles et al., 2015; Emersic et al., 2015; O'Sullivan et al., 2014; Niedermeier et al., 2015; Whale et al., 2014). Therefore, the representation of K-feldspar in atmospheric models is important for obtaining a realistic representation of ice nucleation by mineral dust. We have previously represented ice nucleation on a global scale by K-feldspar aerosols (Wilson et al., 2015; Atkinson et al., 2013). In this study we will take a similar approach to estimate the contribution of $\mathrm{K}$-feldspar aerosol to global INP concentrations.

Some marine aerosol particles act as ice-nucleating particles. Early evidence for a relationship between phytoplankton and marine INPs was found by Schnell and Vali (1975) and Schnell and Vali (1976), who observed active INPs at temperatures as high as $-4{ }^{\circ} \mathrm{C}$ in resuspended biological material, largely from phytoplankton filtered from bulk sea water. A relationship between the amount of biological material and the INP concentration was also measured in sea water and fog water by Schnell (1977). More recent studies have measured ice nucleation by Thalassiosira Pseudonana (a ubiquitous species of phytoplankton) diatom cells (Knopf et al., 2010; Alpert et al., 2011) and exudates (Wilson et al., 2015). However, these studies measured ice nucleation at significantly lower temperatures than those measured by Schnell and Vali (1975), and Schnell and Vali (1976), suggesting that more active INPs could be associated with phytoplankton material in the ocean. This would be supported by a previous measurement of ice-nucleating bacteria associated with phytoplankton cultures (Fall and Schnell, 1985). Further evidence for the biological origin of marine INPs is the heat sensitivity of some types of organic INPs; i.e. the temperature at which they nucleate ice is reduced after heating to $100^{\circ} \mathrm{C}$ (Wilson et al., 2015; Schnell and Vali, 1975, 1976). The likelihood of a marine source of INPs was highlighted in studies that measured INP concentrations in environments remote from other sources of INPs (Bigg, 1973; Schnell, 1982; Rosinski et al., 1986; Bigg, 1996; Rosinski et al., 1987, 1988).

The first global simulation of marine INP concentrations (Burrows et al., 2013) suggested that marine organics were likely to be the dominant source of INPs over remote marine regions such as the Southern Ocean. Other studies provide further strong evidence that there is a marine source of atmospheric INPs with a biological origin. For example, INP production associated with phytoplankton blooms has been measured in laboratory experiments that use artificially generated sea-spray aerosol from wave and bubble tanks (Wang et al., 2015; DeMott et al., 2016). DeMott et al. (2016) measured the INP concentrations in laboratory-generated sea spray as being consistent with measurements made by Bigg (1973) as well as with measurements of ambient INP concentrations in marine-influenced air. Wilson et al. (2015) found that the sea-surface microlayer is enriched with INPs compared to subsurface seawater at the same locations. The sea-surface microlayer is enriched with surface active organic material similar to that found in sea spray (Cochran et al., 2016; Gantt et al., 2011; Quinn et al., 2014; Aller et al., 2005; Orellana et al., 2011; Russell et al., 2010; Cunliffe et al., 2013). A correlation between total organic carbon content and the temperature at which microlayer droplets froze was measured (Wilson et al., 2015).

All the above evidence suggests the existence of a marine organic source of ice-nucleating particles that we will attempt to represent in this paper.

Here we conduct a modelling study of global immersionmode INP concentrations based on recently developed laboratory-based parameterizations of the ice-nucleating ability of two species: marine organic matter and potassium feldspar (K-feldspar). The objectives of our study are to (i) determine the ability of laboratory-measured INP efficiencies to explain the global distribution of INP concentrations as a function of activation temperature, (ii) quantify the relative importance of these two sources of INPs in different 
locations, (iii) determine what fraction of global INP concentrations can be explained by these two sources and (iv) determine whether, within model and measurement uncertainties, we can use the model results to draw conclusions about additional important sources of INPs.

\section{Methods}

\subsection{Global modelling}

We use the GLOMAP-mode global aerosol model described in Mann et al. (2010). The model has a horizontal latitudelongitude grid spacing of $2.8^{\circ} \times 2.8^{\circ}$ and 31 pressure levels from the surface to $10 \mathrm{hPa}$. The species represented in the baseline version are sulfate, sea salt, black carbon, particulate organic matter and dust. In this study we focus on the representation of two species of relevance to INPs: the Kfeldspar component of dust and the organic component of primary marine sea-spray aerosols. Aerosol chemical component mass concentrations and the particle number concentration are represented by seven internally mixed lognormal modes (four soluble and three insoluble). Aerosol microphysical processes in the model include nucleation of new particles by gas-to-particle conversion, growth by coagulation and condensation of low-volatility gases, dry deposition at the surface and below-cloud (impaction) and incloud (nucleation) wet scavenging. Nucleation scavenging is suppressed for ice clouds, which are assumed to glaciate at $-15^{\circ} \mathrm{C}$. A discussion of the nucleation scavenging assumptions in our model is included in Browse et al. (2012). Scavenging of aerosols by marine drizzle clouds is also included in the model to improve the predicted concentration in polar regions, as shown in Browse et al. (2012). The model uses wind, temperature and humidity fields from the European Centre for Medium-Range Weather Forecasts (ECMWF). We ran the model from the year 2000 to 2001 in order to reach a steady state aerosol distribution before running the model and then used data from 2001 to 2002.

\subsection{Representation of feldspar}

Feldspar is emitted in the model as a fraction of the mass of dust (derived from AEROCOM emissions; Dentener and Kinne, 2006). The model has been shown to reproduce dust mass concentrations within an order of magnitude (Mann et al., 2010; Huneeus and Schulz, 2011). The fraction of feldspar emitted is assumed to be equal to the fraction by mass of this mineral found in the soils in the arid emission regions. This assumption has been shown to be a close approximation of the fraction of the mineral emitted in the form of aerosols (Lafon et al., 2004; Nickovic et al., 2012). However, new studies suggest that there is a difference between the fraction of the minerals found in the soil after wet sieving and the aerosolized fraction (Perlwitz et al., 2015). This difference is considered to be small (around a factor of 2) compared to other errors in our representation of the icenucleating ability of K-feldspar such as differences in the density of active sites of different types of K-feldspar (around a factor of 6; Harrison et al., 2016).

Feldspar is emitted into the insoluble accumulation and coarse modes with fractions corresponding to the clay and silt size range (Lafon et al., 2004; Nickovic et al., 2012), similar to the method followed in Atkinson et al. (2013). However, once in the atmosphere, dust particles (including feldspar) are aged by condensation of sulfates and secondary organic aerosol material and moved into the soluble modes, which are subject to wet scavenging. This process was not represented in Atkinson et al. (2013), and was likely one of the causes of the overestimation of dust concentrations in remote locations as discussed in Atkinson et al. (2013). With this wet scavenging process being active, the concentration of feldspar in remote places such as the Southern Ocean is several orders of magnitude smaller than the concentrations simulated by Atkinson et al. (2013). However, the concentrations closer to source regions are very similar to Atkinson et al. (2013).

Feldspar tends to reside in the larger particles because it is found mainly in the silt fraction $(r>1 \mu \mathrm{m}$; Claquin et al., 1999). It is therefore removed more rapidly from the atmosphere compared with other minerals that occur preferentially in the clay fraction because removal by dry deposition increases with particle size. Relatively rapid scavenging of large feldspar-containing particles means that it is transported shorter distances compared with smaller dust particles.

\subsection{Representation of marine organic aerosols}

Submicron marine organic aerosols are usually parameterized by relating the organic mass fraction observed in sea spray to some variables such as seawater chlorophyll content or wind speed (O'Dowd et al., 2015; Rinaldi et al., 2013; Gantt et al., 2011). With those parameterizations, the flux of marine organic mass can be calculated in a model with the flux of submicron sea salt following Eq. A5 (see Appendix). The performance of any parameterization in reproducing observations of marine organic mass concentrations will therefore depend on the emission fluxes of submicron sea spray, which is a highly uncertain model-dependent process. Mann et al. (2014) showed that models can have differences of more than a factor of 6 in the simulated concentration of particles with a diameter larger than $100 \mathrm{~nm}$ in the Southern Ocean. Other uncertainties affecting the modelled concentrations of marine organic aerosols can arise from removal processes or some other aspect of the model such as the parameterization of convection and cloud microphysical processes, or model grid and temporal resolution, as well as uncertainties related to the organic mass fraction parameterization. Therefore, the performance of any parameterization in an aerosol model will be affected by the uncertainties re- 
lated to these processes. It is therefore necessary to evaluate and adjust the modelled marine organic concentrations to match observations.

To represent primary marine organic aerosols in GLOMAP mode, we developed a parameterization of the organic mass fraction of submicron sea-spray particles and adjusted it to fit the observations of water insoluble organic matter (WIOM) at Amsterdam Island $\left(37.48^{\circ} \mathrm{S}\right.$, $\left.77.34^{\circ} \mathrm{E}\right)$ and Mace Head $\left(53.33^{\circ} \mathrm{N}, 9.9^{\circ} \mathrm{W}\right)$. We use observations from only these two stations due to the limited availability of long-term measurements of marine WIOM. It is thought that most primary marine organic emissions are formed of water-insoluble components (Facchini et al., 2008). The marine organic component is assumed to be internally mixed with sea salt. The sea-salt emissions in our model are dependent on the surface wind speed $(10 \mathrm{~m}$ above the surface) and follow the parameterization of Gong (2003), which is an extension of Monahan et al. (1986). The development of our new organic mass fraction parameterization, explained in detail in Appendix A, assumes that the organic mass fraction of the sea-spray particles depends on wind speed and the chlorophyll content of seawater. The organic emission parameterization includes a positive dependence of WIOM mass fraction on chlorophyll (O'Dowd et al., 2015; Rinaldi et al., 2013; Gantt et al., 2011), but a negative dependence on wind speed. Thus, the WIOM is essentially diluted in the sea-spray particles when the total sea-spray emission flux is high, which may be caused by a limited supply of organic material in the surface ocean but effectively limitless salt (Gantt et al., 2011). This parameterization is similar to previous chlorophyll-based parameterizations such as Rinaldi et al. (2013) and Gantt et al. (2011) but adjusted in order to fit the observations in Amsterdam Island and Mace Head when applied in our model. Our model agrees with the observed WIOM concentrations within a factor of 2 (Fig. 1) which is a small factor compared with other uncertainties related to the calculation of INP concentrations such as the uncertainty related to the parameterization of the number of INP per gram of organic carbon in sea water (around an order of magnitude; Wilson et al., 2015).

The mixed organic-salt sea-spray particles are emitted into the accumulation mode and treated as water-soluble particles with respect to their cloud condensation nuclei activity, and hence they are removed by nucleation scavenging when they enter a precipitating cloud. This treatment of primary marine organic mass as being internally mixed with sea salt and able to activate to cloud droplets is consistent with other previous studies (Vignati et al., 2010; Burrows et al., 2013; Orellana et al., 2011; Ovadnevaite et al., 2011; Fuentes et al., 2011; Partanen et al., 2014). Simulated surface concentrations of marine organic aerosol mass are shown in Fig. 2.

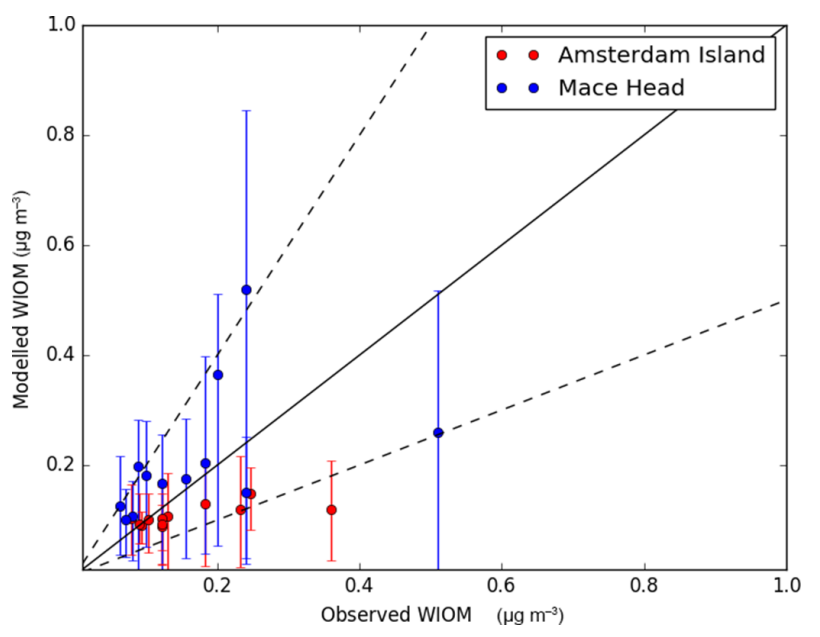

Figure 1. Evaluation of modelled water-insoluble organic matter (WIOM) mass concentration with monthly mean observations at Mace Head $\left(53.33^{\circ} \mathrm{N}, 9.9^{\circ} \mathrm{W}\right)$ and Amsterdam Island $\left(37.48^{\circ} \mathrm{S}\right.$, $\left.77.34^{\circ} \mathrm{E}\right)$. The dashed lines correspond to a difference of a factor of 2 between modelled and observed values. The error bars correspond to the simulated daily variability within a month (maximum and minimum values). Variability in the observed values is not shown because the measurements were made with filter samples which were collected over 1 week, and therefore they do not represent the day-to-day variability.

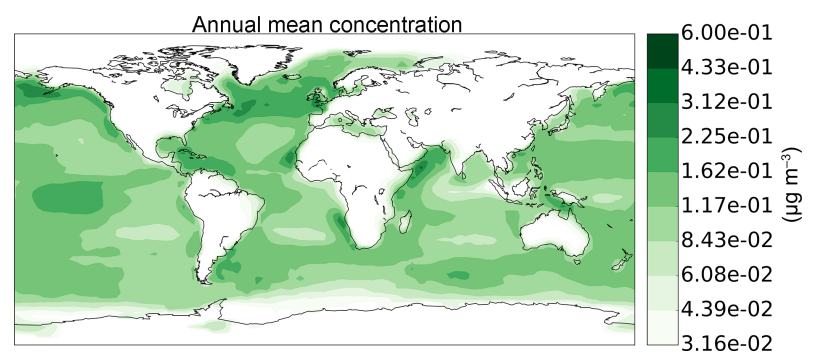

Figure 2. Annual mean modelled mass concentration of submicron marine organic aerosol at surface level.

\subsection{Calculation of INP concentrations}

To quantify INP concentrations from the modelled aerosol distributions we use the singular description. This method assumes that the time dependence of ice nucleation plays a secondary role and that specific particles have a characteristic temperature at which they nucleate ice. The spectrum of ice-nucleating properties is often represented as a surface area density of active sites dependent on temperature, which is appropriate for solid particles like dust (Atkinson et al., 2013). For marine organic material the active site density is defined per unit mass of organic material in the particle (Wilson et al., 2015).

The method for calculating ice-nucleating particle concentrations from the simulated aerosol size distributions is explained in Appendix B. 
To represent the ice-nucleating ability of K-feldspar we assume that $35 \%$ of the total feldspar is K-feldspar, as assumed in Atkinson et al. (2013), then we apply the parameterization for $n_{\mathrm{S}}$ shown in Atkinson et al. (2013). Our method assumes that different varieties of $\mathrm{K}$-feldspar nucleate ice with the same efficiency. Different studies have shown that the values of $n_{\mathrm{s}}$ for most types of K-feldspar tend to agree with the values shown in Atkinson et al. (2013) within a factor of 2 to 4 (Harrison et al., 2016; Emersic et al., 2015; O'Sullivan et al., 2014; Zolles et al., 2015; Niedermeier et al., 2015; Whale et al., 2014). However, it should be borne in mind that a minority of feldspar samples are either much more active or much less active than indicated by Atkinson et al. (2013). Nevertheless, the Atkinson parameterization is a good approximation of the majority of K-feldspars that have been studied in the laboratory. Assuming that feldspar particles are externally mixed in terms of their mineralogy, we can use the laboratory parameterizations to calculate the INP concentration for each soluble mode, following Eq. B9, as a function of activation temperature (see Appendix B for the derivation).

For marine organic aerosols, we use the parameterization shown in Wilson et al. (2015), and apply it to our distributions of simulated marine organic aerosol mass. We are assuming that the organic material found in the sea-surface microlayer is representative of the organic material in sea-spray aerosols and that this material has the same ice-nucleating ability as sea-surface microlayer material. For marine organic particles the density of active sites per particle is always small $(\lambda<0.1$ see Appendix B) for the whole temperature range covered by the parameterization $\left(-6\right.$ to $\left.-27^{\circ} \mathrm{C}\right)$ and all realistic sizes of particle (submicron particles). This means that we can calculate the INP concentration in a simplified way following Eq. 1 (see Appendix B for the derivation).

$[\mathrm{INP}](T) \approx \lambda(T) \cdot[N]$

It should be noted that extrapolating this parameterization to lower temperatures, or for bigger particles, may lead to unrealistically high concentrations of INPs because Eq. 1 is no longer valid.

There are two distinct ways of presenting simulated INP concentrations - either according to the concentration that an INP counter would measure or the concentration of potential INPs under ambient conditions. An INP is defined as a particle which has the potential to nucleate ice if exposed to a specific set of conditions (much like a $\mathrm{CCN}$ is defined at a specific supersaturation). For the immersion/condensation mode, the INP concentration we quote are for water saturation and for a defined activation temperature. The two ways of quoting INP concentrations (Fig. 4) are at a specific activation temperature $T\left([\mathrm{INP}]_{T}\right)$, which is appropriate for comparison with an INP instrument set to measure at that temperature, or $[\mathrm{INP}]_{\mathrm{ambient}}$ for which the activation temperature is set to the local ambient temperature.

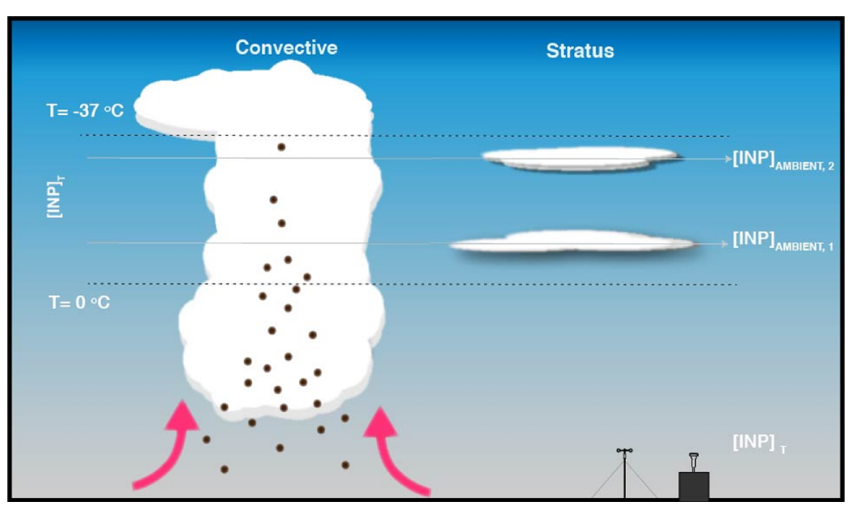

Figure 3. Illustration of the two ways in which we display INP concentrations. It is important to bear in mind that INPs are defined as particles with the potential to nucleate ice and their concentration is quoted for a specific set of conditions. [INP $]_{\text {ambient }}$, where ambient denotes the local atmospheric temperature, is a useful way of looking at the INP concentration relevant to non-deep convective mixedphase clouds. $[\mathrm{INP}]_{T}$, on the other hand, has utility in representing the spectrum of INP concentrations over temperature that will influence clouds with a large vertical extent such as deep-convective systems. Moreover $[\mathrm{INP}]_{T}$ is the relevant quantity when comparing modelled and observed INP concentrations, since measurements are made by exposing particles to controlled temperatures within the instrumentation.

In Fig. 4 (top) we show the INP concentration for an activation temperature of $-20^{\circ} \mathrm{C}\left([\mathrm{INP}]_{-20}\right)$ at the $600 \mathrm{hPa}$ pressure level, which is what would be measured by an INP instrument set to this temperature. Throughout much of the globe, especially through the tropics, the temperature at this pressure level will never reach $-20^{\circ} \mathrm{C}$, so the INPs at this altitude that can be active at $-20^{\circ} \mathrm{C}$ or warmer would not fulfil their potential to nucleate ice. However, if the air at a particular altitude was drawn into a convective system, the INPs it contains would activate higher in the cloud. Hence, when considering a deep convective cloud in which air is moved vertically through all the temperature range of mixedphase clouds, it is the spectrum of $\left[\mathrm{INP}_{T}\right.$ (a spectrum over activation temperature) which is the pertinent quantity (see Fig. 3 for an illustration). In addition, when comparing measurements of [INP] concentration to our modelled [INP], we compare these quantities at specific activation temperatures. Hence, Fig. 4 (top) provides the [INP] to compare it to a measurement of [INP] for which the activation temperature in a measurement was $-20^{\circ} \mathrm{C}$.

In Fig. 4 (bottom) we plot the [INP] for which the activation temperature is set to the local atmospheric temperature. [INP] $]_{\text {ambient }}$ is useful for identifying regions in the atmosphere where we might expect cloud glaciation in stratustype mixed-phase clouds. Non-deep convective clouds with minimal vertical extent, such as altostratus, altocumulus or high-latitude stratus, form in air parcels which have not been vertically transported large distances, in contrast to deep 


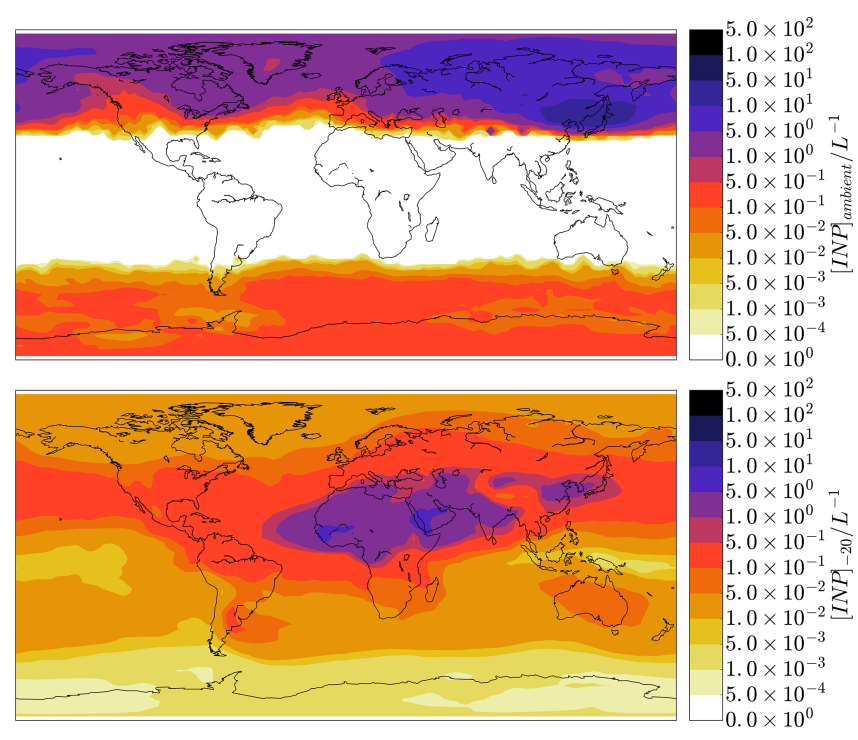

Figure 4. Annual mean K-feldspar INP distribution using GLOMAP mode at a pressure level of $600 \mathrm{hpa}$. Top panel shows the concentration of ice-nucleating particles active at a temperature of $-20^{\circ} \mathrm{C}\left([\mathrm{INP}]_{T}\right)$ whereas the bottom panel shows the INP concentration at local ambient temperature ([INP $\left.]_{\text {ambient }}\right)$.

convection. Based on Fig. 4 (bottom), we would expect Kfeldspar to contribute much more to midlatitude, mid-level $(600 \mathrm{hPa})$, mixed-phase clouds in the Northern Hemisphere than in the Southern Hemisphere.

Both [INP $]_{T}$ and [INP $]_{\text {ambient }}$ are useful ways of looking at the global INP distribution, but in order to understand the impact of these INP species on clouds, we would need a model in which the INP fields are coupled to cloud microphysics and dynamics. This is beyond the remit of this study, where our goal is to understand the global distribution of INPs and evaluate the model against measurements.

To calculate $[\mathrm{INP}]_{\mathrm{ambient}}$, we use the daily mean temperatures obtained from ECMWF and the daily mean concentrations (mass and number concentrations) predicted by the model. The daily values are then averaged to calculate monthly and annual mean values of INPs. The concentrations of [INP $]_{\mathrm{ambient}}$ at temperatures lower than the temperature limit of the parameterizations $\left(-25^{\circ} \mathrm{C}\right.$ for $\mathrm{K}$-feldspar and $-27^{\circ} \mathrm{C}$ for marine organics) are set at the value defined by the concentration at the limiting temperature of each parameterization. This is consistent with studies that caution against extrapolating singular parameterizations outside the range in which measurements were made. For example, Niedermeier et al. (2015) showed that the density of active sites on the surface of K-feldspar particles plateaus below about $-25^{\circ} \mathrm{C}$ and a simple extrapolation of the parameterization of Atkinson et al. (2013) would lead to substantial errors.

\section{Results}

\subsection{Simulated global INP distributions}

Simulated INP concentrations at the surface are shown in Fig. 5 for an activation temperature of $-15^{\circ} \mathrm{C}$. Feldspar dominates the INP concentration in environments influenced by terrestrial dust emission sources such as the Sahara and the Asian dust belt. However, concentrations fall rapidly with distance from dust sources because the large-sized feldsparcontaining dust particles are rapidly removed from the atmosphere (Fig. 5a). The concentrations of INPs from K-feldspar and marine organics are summarized in Fig. 5. Comparison with panels a and $b$ reveals that INPs from deserts far outnumber INPs from sea spray throughout much of the low latitudes and midlatitudes, which are strongly influenced by desert dust, while marine organics are becoming more important over the world's remote oceans, such as the Southern Ocean.

Figure 6 shows the $[\mathrm{INP}]_{\text {ambient }}$ concentration of marine organics and K-feldspar for the different seasons. Feldspar dominates $[\mathrm{INP}]_{\text {ambient }}$ on a monthly mean basis across the Northern Hemisphere, while marine organic aerosols tend to be important in southern high latitudes, such as those corresponding to the Southern Ocean and Antarctica.

The seasonal mean results in Fig. 6 have to be interpreted with caution since high dust concentrations are often associated with episodic dust plumes. Hence, the seasonal mean may not reflect the relative contributions of desert dust and sea-spray INPs on a day-to-day basis. In addition, day-today fluctuations in temperature can drive large changes in $[\mathrm{INP}]_{\text {ambient }}$ which are not necessarily representative of the typical concentrations of active ice-nucleating particles, but will greatly affect the monthly mean value of $[\mathrm{INP}]_{\text {ambient }}$, as the INP concentration increases exponentially with temperature. To account for such variability, Fig. 7 shows the percentage of days per season when the concentration of $[\mathrm{INP}]_{\text {ambient }}$ from marine organics is greater than the concentration from K-feldspar. Overall, over the Northern Hemisphere, marine organic INP concentrations are greater than K-feldspar INP concentrations between 10 and $30 \%$ of the days when the temperature is within the mixed-phase range $\left(0\right.$ to $\left.-37^{\circ} \mathrm{C}\right)$ and the total concentration of $[\mathrm{INP}]_{\mathrm{ambient}}$ is larger than $10^{-4} \mathrm{~L}^{-1}$. This large influence of marine organic INP is hidden when looking at the monthly mean values shown in Fig. 6 as the feldspar monthly mean concentrations are dominated by short periods during which a dust plume occurs. It is striking that the contribution of marine organics is more important than $\mathrm{K}$-feldspar on a significant fraction of days in the Northern Hemisphere because in these zonal mean plots we are averaging across the Eurasian and North American continents where the influence of marine organics is minor. In fact, Fig. 7 suggests that marine organics are more important than K-feldspar in the North Atlantic, for example, on $10-40 \%$ of days at $600 \mathrm{hPa}$. 


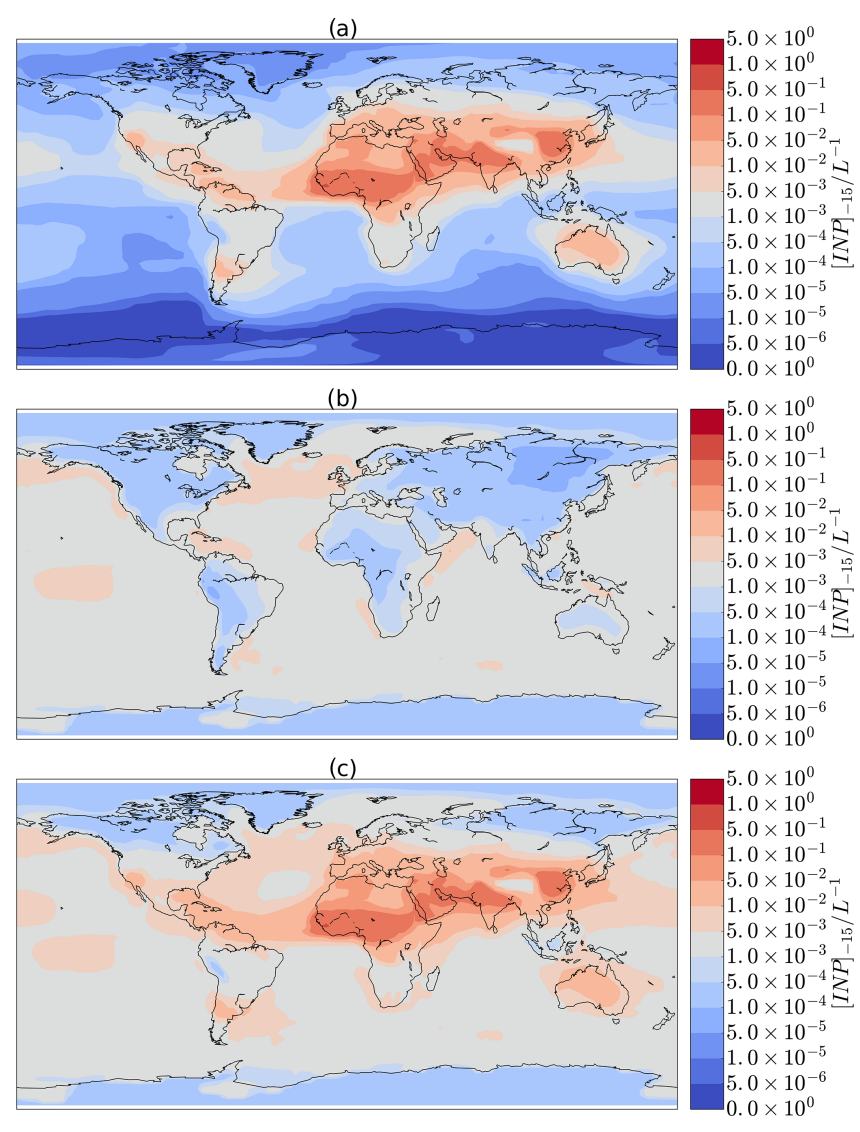

Figure 5. Annual mean distributions of ice-nucleating particles concentrations, for an activation temperature of $-15^{\circ} \mathrm{C}$ based on feldspar (a) and marine organics (b). Panel (c) shows the total INP concentration obtained by summing the INP concentrations from Kfeldspar and marine organics. We show $[\mathrm{INP}]_{T}$ for a $T$ of $-15^{\circ} \mathrm{C}$ because this is a temperature used by many instruments. The number of INP that activate to ice crystals ([INP $]_{\text {ambient }}$ ) at the surface will be zero over much of the globe, because these particles will only become important at high altitudes. Surface concentrations are shown because this is where most observations of atmospheric INP concentrations are made.

In the Southern Hemisphere, the dominance of marine organic aerosols is more prevalent. On a monthly mean basis and on the large majority of days, marine organic aerosols are the dominant INPs from March through to November (Fig. 6b-d). On the other hand, K-feldspar cannot always be ruled out as an important source of INPs in the southern high latitudes in the period from March to November, since there are still several days per month (10 to $60 \%)$ when the concentration of transported K-feldspar INPs dominates over marine organics (Fig. 6). Conversely, during December to February at southern high latitudes, K-feldspar mineral dust is more important on more days than marine organic aerosols (Fig. 7a). This is related to higher dust concentrations during the austral summer.

\subsection{Comparison with observations and other parameterizations}

Some climate models determine heterogeneous freezing using parameterizations that depend only on the temperature, (McCoy et al., 2015) such as the scheme of Meyers et al. (1992). This type of parameterization does not account for spatial or temporal variations in the aerosol loading and does not differentiate between different aerosol species; both of these factors actually determine INP concentrations. Other parameterizations such as DeMott et al. (2010) use empirical evidence from extensive atmospheric measurements to define INP concentrations in terms of the aerosol particle concentration above a defined size.

Such parameterizations implicitly account for the fact that many INP-active species are present in larger particles, such as in dust (Niemand et al., 2012) and biological particles (Tobo et al., 2013). In addition, larger particles are more likely to carry nanoscale or smaller ice active materials (O'Sullivan et al., 2015). Nevertheless, size-based parameterizations of INP concentration do not account for the source of the particles or differences between marine and terrestrial aerosols, so they may not capture variations and long-term trends driven by changes in aerosol emissions since different aerosol types have different ice-nucleating abilities.

In Fig. 8 we compare several singular INP parameterizations with observations. Panel a compares the observed values of $[\mathrm{INP}]_{T}$ to those predicted by the scheme of Meyers et al. (1992), which relates [INP] $]_{T}$ to temperature and is independent of aerosol properties. This is clearly a poor representation of many INP measurements in the atmosphere (Table 1). Figure $8 \mathrm{~b}$ shows the $[\mathrm{INP}]_{T}$ predicted by the parameterization of DeMott et al. (2010), in which [INP] $]_{T}$ is predicted on the basis of the concentration of particles larger than $0.5 \mu \mathrm{m}$ diameter, $n_{\mathrm{aer}, 0.5}$, and temperature. This parameterization tends to overpredict $[\mathrm{INP}]_{T}$, although multiplicative scaling of the simulated values would greatly improve its performance as it has a better correlation coefficient (Table 1). We also note that in our analysis we use the annual mean $n_{\text {aer }, 0.5}$ from our model (without the contribution of sea-salt aerosols), whereas DeMott et al. (2010) used $n_{\text {aer }, 0.5}$ from measurements coincident with their INP measurements and obtained a better representation of the $[\mathrm{INP}]_{T}$ data (some of which is included in Fig. 8). Sulfate aerosols contribute significantly to the simulated $n_{\text {aer }, 0.5}$ in remote places impacting DeMott et al. (2010) over oceans.

Figure 8c shows how our model compares with observed $[\mathrm{INP}]_{T}$ using the desert dust parameterization from Niemand et al. (2012) (with no additional marine organic INPs). In this case some observations are overestimated by a factor 1001000 , especially those in marine regions (triangles). A similar trend is observed when this parameterization is extrapolated at higher temperatures. This overprediction is partly caused by the implicit assumption that all components of dust particle nucleate ice with the same efficiency. Feldspars exist 

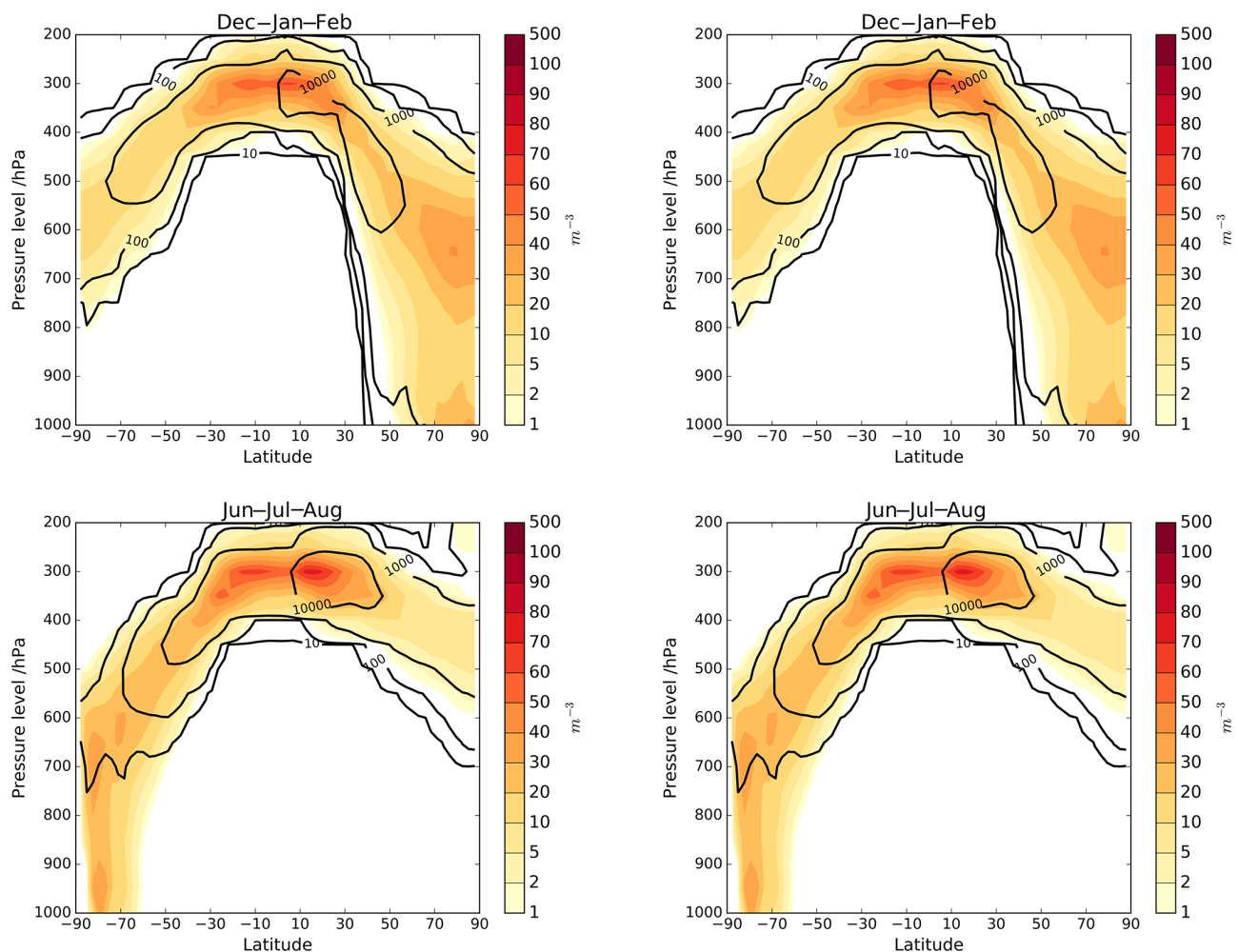

Figure 6. Zonal mean profiles of $[\mathrm{INP}]_{\mathrm{ambient}}$ for every month of the year. The black contour lines correspond to the INP concentration of $\mathrm{K}$-feldspar aerosols $\left(\mathrm{m}^{-3}\right)$, while the colour map shows the INP concentration of marine organic aerosol The values correspond to seasonal mean values calculated using daily concentrations and temperatures and averaged across latitudes.
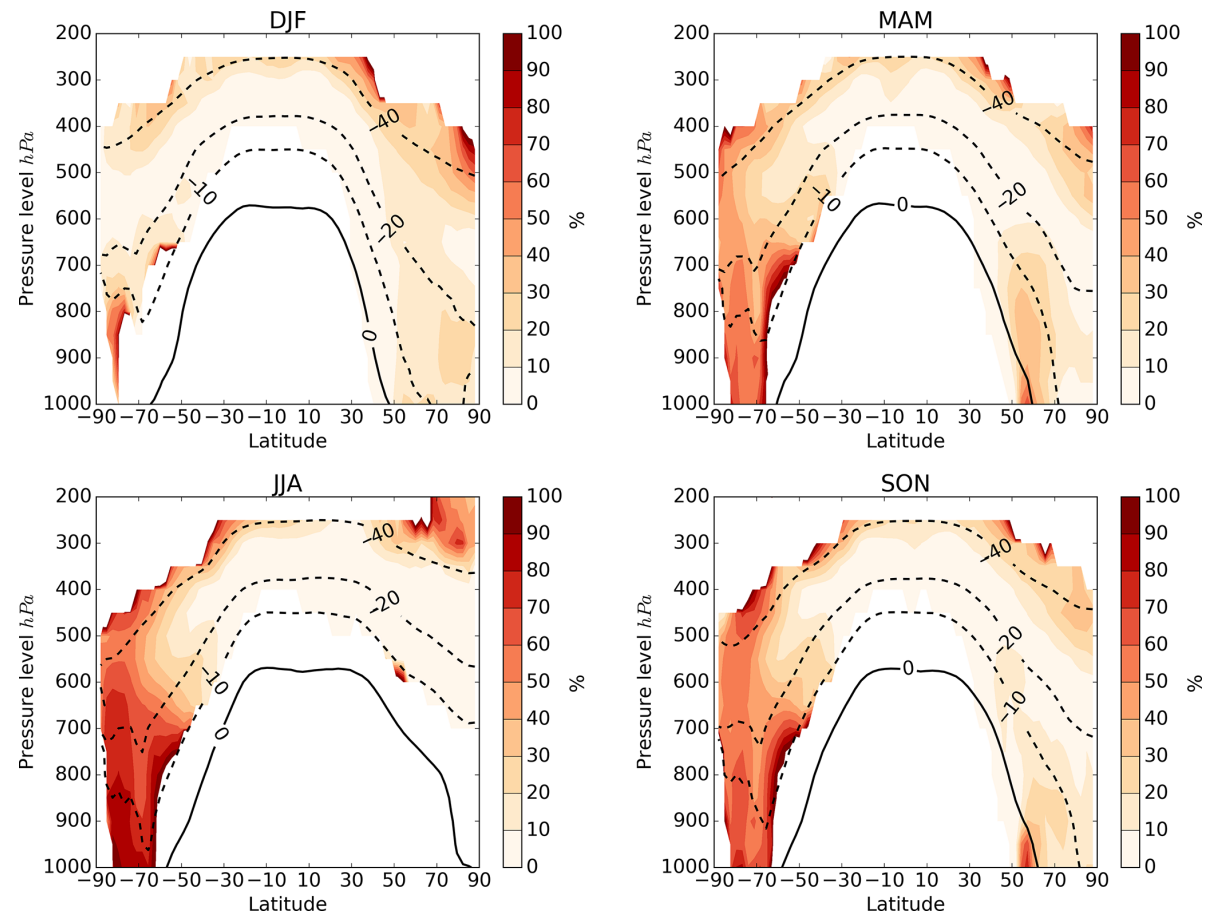

Figure 7. Percentage of days when $[\mathrm{INP}]_{\text {ambient }}$ from marine organic aerosols is greater than from K-feldspar. The number of days have been calculated only for times and locations where the total $[\mathrm{INP}]_{\mathrm{ambient}}$ concentration is larger than $0.1 \mathrm{~m}^{-3}$. The black contour lines represent seasonal mean isotherms in degrees centigrade. 

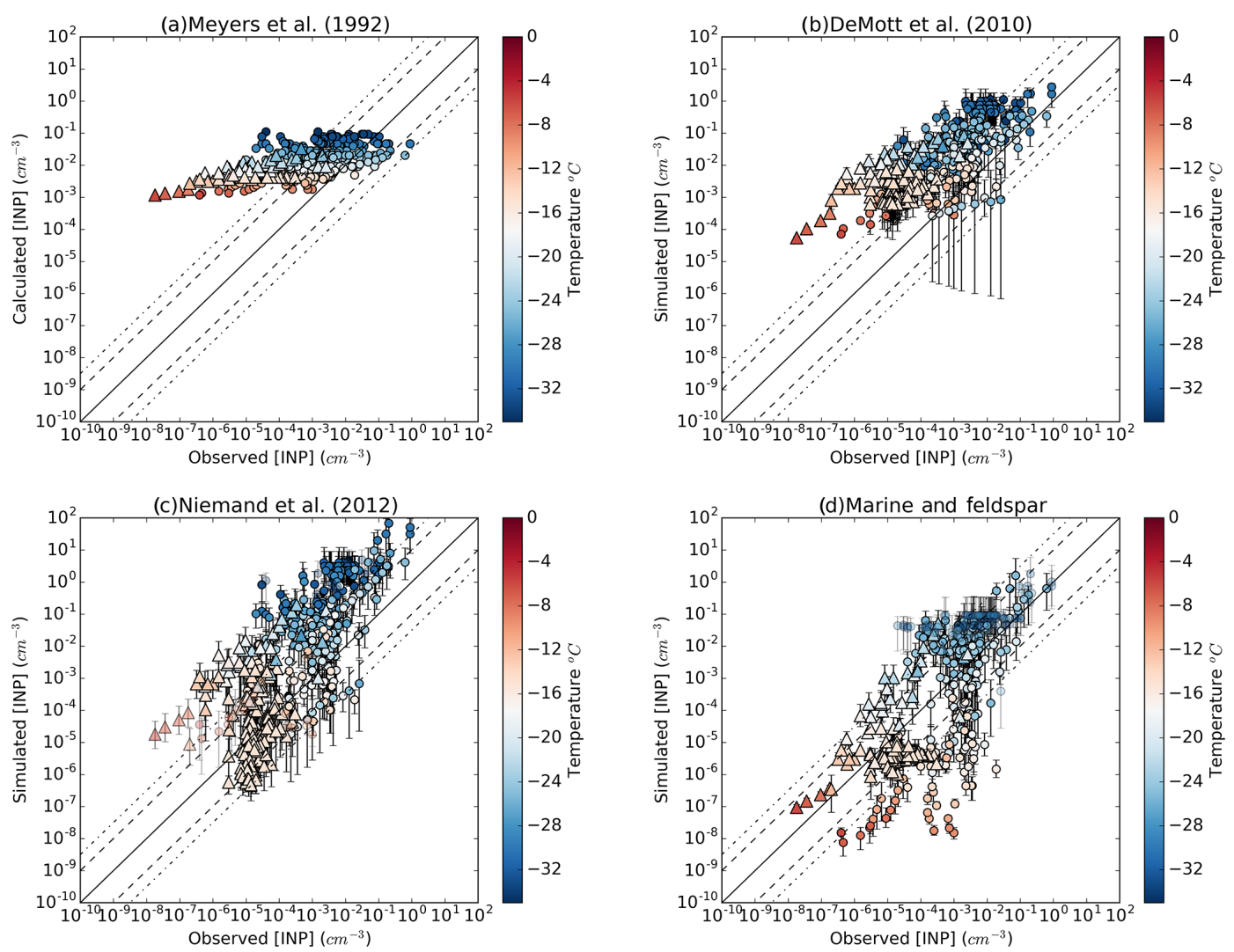

Figure 8. Comparison of the performance of a variety of INP parameterizations tested against field measurements. (a-d) Modelled INP concentration values when using (a) Meyers parameterization (Meyers et al., 1992), (b) DeMott's parameterization (DeMott et al., 2010) combined with a global aerosol simulation using GLOMAP mode, (c) Niemand dust parameterization (Niemand et al., 2012) and (d) our twospecies representation based on feldspar (Atkinson et al., 2013) and marine organic aerosols (Wilson et al., 2015). Triangles represent marine influenced regions and points terrestrial environments. The light shaded points in (d) and (e) are for data points outside the temperature range of the parameterizations. The dashed lines represent one order of magnitude of difference between modelled and observed and the dasheddotted lines 1.5 orders of magnitude. The simulated values correspond to an annual mean concentration and the error bars correspond to the simulated seasonality of INPs calculated with monthly mean values. For each individual observation, we calculated the INP concentration at the temperature corresponding to the temperature that aerosol particles were exposed to in the INP instruments. The locations of the data point are shown in Fig. 9.

mainly in the large dust particles (silt fraction) so they are not transported as efficiently to remote locations as the clay minerals; consequently transported desert dust is less important than an INP in remote locations.

Finally, we compare our two-species representation of INPs with the same $[\mathrm{INP}]_{T}$ data set Fig. $8 \mathrm{~d}$. The observations used in this comparison are within the range of temperatures of the parameterizations $\left(-5\right.$ to $\left.-27^{\circ} \mathrm{C}\right)$. In this case our representation of INPs (Fig. 8d) is able to reproduce $56.7 \%$ of the observations within an order of magnitude and $74 \%$ within 1.5 orders of magnitude (Table 1). When the parameterizations are extrapolated outside their temperature range, they still perform similarly (Table 1). Looking at the performance of the different ways of representing INPs within the smallest temperature range shared by the all the parameterizations $\left(-12\right.$ to $\left.-25^{\circ} \mathrm{C}\right)$, our representation of INPs is able to reproduce $61.6 \%$ of the data points within an order of magnitude and $78.7 \%$ within 1.5 orders of magnitude. These values are greater than that obtained when using the other three parameterizations used for this study (Table 1).

The contributions of K-feldspar and marine organics to the simulated INP concentrations of each data point are illustrated in Fig. 9b. Marine organics explain more than $90 \%$ of the INP concentrations in marine-influenced environments and some terrestrial environments with low concentrations of INPs (corresponding to high temperature observations). $\mathrm{K}$-Feldspar, however, explains most of the observations in terrestrial regions. The large biases observed when using species independent parameterizations over marine regions are largely corrected, as most marine influenced INP concentrations are simulated within an order of magnitude ( $72 \%$ of marine points), although some biases are still apparent. Figure 10 shows the location and temperature of the observations with a bias greater than 1.5 orders of magnitude. Fig- 

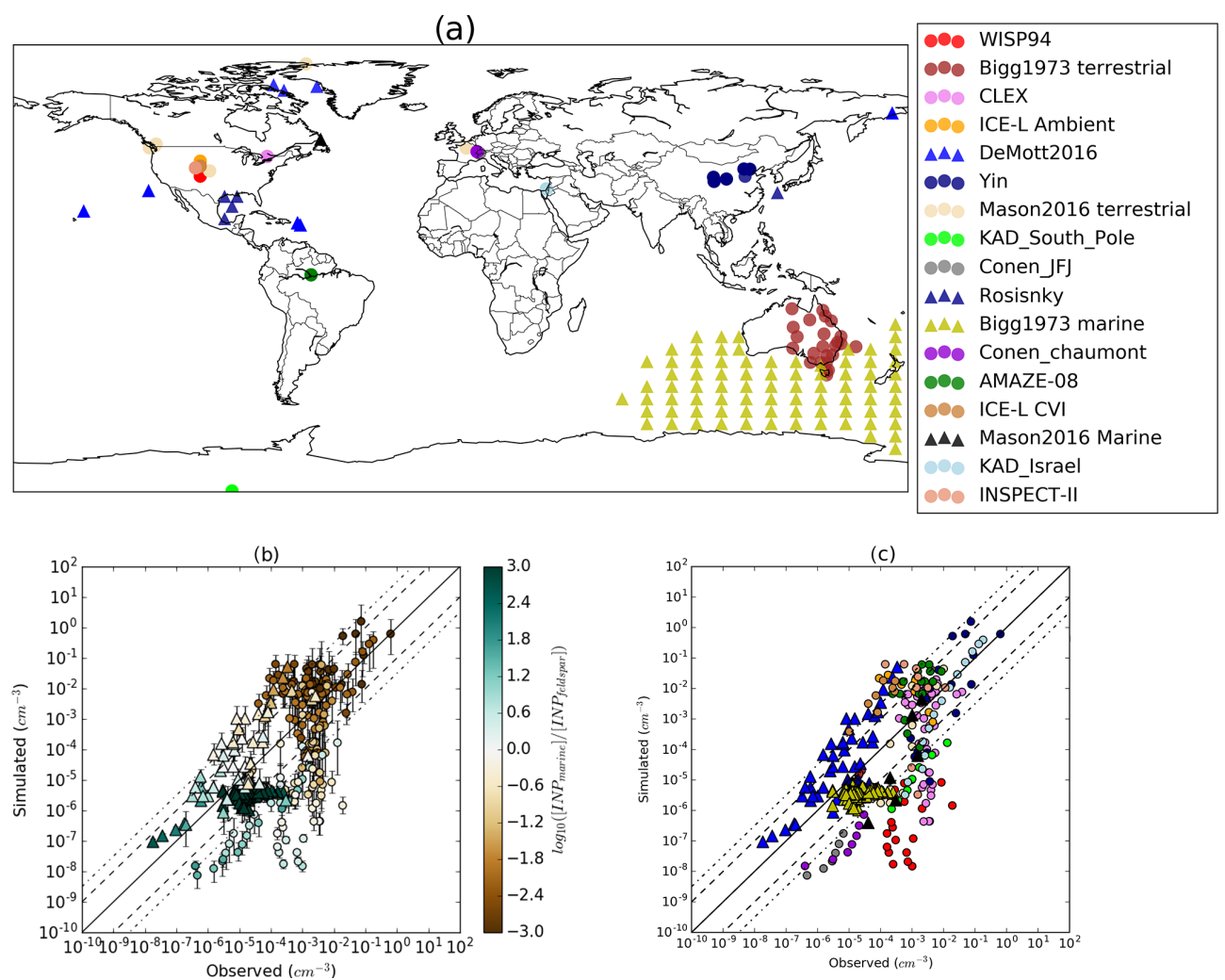

Figure 9. (a) Location of the data used for comparison in Fig. 8. (b) Same as Fig. 8d but showing the relative contribution (in orders of magnitude) of each aerosol species to the simulated concentration. (c) Same as (b) but distinguishes between the different campaigns shown in (a) (with the same colours and symbols). References to the data sets used are shown in Appendix C.

ure 10a suggests that the main positive bias occurs at low temperatures $\left(<-20^{\circ} \mathrm{C}\right)$ in locations far from K-feldspar emission sources, where it is transported. It is possible that processes such as atmospheric ageing by acids play a role in modifying the efficiency of K-feldspar aerosols in nucleating ice (Augustin-Bauditz et al., 2014) or that we overestimate the amount of feldspar particles that are transported. One possible explanation for this is that we do not model the preferential removal of INPs during cloud glaciation; hence K-feldspar aerosol transported over long distances may contain fewer INPs than our model simulations (Stopelli et al., 2015; Haga et al., 2014, 2013). Figure 10b shows that the model underestimates high-temperature INP concentrations $\left(\sim-5\right.$ to $\left.-15^{\circ} \mathrm{K}\right)$ over terrestrial locations, which might indicate that we are missing some terrestrial source that affects the INP concentration. Some of the possible candidates for these particles could be bacteria (Möhler et al., 2008; Hartmann et al., 2013; Maki and Willoughby, 1978), fungal material (O'Sullivan et al., 2015, 2016; Fröhlich-Nowoisky et al., 2015; Pouleur et al., 1992; Morris et al., 2013), agricultural dust (O'Sullivan et al., 2014; Tobo et al., 2014; Garcia et al., 2012) or biological nanoscale fragments attached to mineral dust particles (O'Sullivan et al., 2015, 2016; Pummer et al., 2015; Fröhlich-Nowoisky et al., 2015). However, size- resolved INP measurements in several terrestrial locations suggest that a large proportion (40-90\%) of INPs are commonly associated with larger particles (diameter $>2.5 \mu \mathrm{m}$; Mason et al., 2016). Such large particles are likely to have short atmospheric lifetimes, so they are less likely to be transported to cloud altitudes than smaller particles and are more likely to be transported shorter distances. In summary, the overall agreement between the two-species model and observations is good, but there are significant discrepancies. These discrepancies indicate that processes such as ageing and preferential INPs in-cloud removal could be important and also that we could be missing high-temperature terrestrial sources of INPs in the model.

\section{Conclusions}

This study is a step towards the inclusion of ice-nucleating particles in weather and climate models in a way that accounts for the aerosol chemical composition using laboratory-derived parameterizations under the singular description. We find that marine organic aerosols dominate the concentration of INPs in remote locations like the Southern Ocean on many days, whereas feldspar particles are the dominant species for ice nucleation in places influenced by the 
Table 1. Statistical performance of the different parameterizations. Pt1 and Pt1.5 are the percentages of data points reproduced within an order of magnitude and 1.5 orders of magnitude in the temperature range of every parameterization. The number of data points used for calculating these values is shown under the data points column. The values with ${ }^{*}$ show the same calculation but include data points outside the temperature range of the parameterizations. These values give an idea of the performance that you would expect if you extrapolate the parameterizations in a climate model. The values with ${ }^{* *}$ are for data points within the smallest temperature range shared by the four parameterizations $\left(-12\right.$ to $\left.-25^{\circ} \mathrm{C}\right)$. The correlation coefficient has been calculated with the logarithm of the values as INP concentrations vary logarithmically with temperature.

\begin{tabular}{|c|c|c|c|c|c|c|c|c|c|c|c|}
\hline Parameterization & Temperature range & Data points & Pt1 & Pt1.5 & $\mathrm{R}$ & Pt1 ${ }^{*}$ & Pt1.5* & $R^{*}$ & $\mathrm{Pt} 1^{* *}$ & $\mathrm{Pt} 1.5^{* *}$ & $R^{* *}$ \\
\hline Meyers et al. (1992) & 0 to $-37{ }^{\circ} \mathrm{C}$ & 479 & $35.5 \%$ & $51 \%$ & 0.57 & $35.5 \%$ & $51 \%$ & 0.57 & $27.4 \%$ & $39.4 \%$ & 0.47 \\
\hline DeMott et al. (2010) & 0 to $-37^{\circ} \mathrm{C}$ & 479 & $24 \%$ & $39.2 \%$ & 0.67 & $24 \%$ & $39.2 \%$ & 0.67 & $23.6 \%$ & $38.3 \%$ & 0.42 \\
\hline Niemand et al. (2012) & -12 to $-33^{\circ} \mathrm{C}$ & 438 & $33.7 \%$ & $53 \%$ & 0.58 & $31.7 \%$ & $53 \%$ & 0.64 & $46.9 \%$ & $70 \%$ & 0.41 \\
\hline Marine and K-feldspar & -6 to $-25^{\circ} \mathrm{C}$ & 354 & $56.7 \%$ & $74 \%$ & 0.62 & $54.9 \%$ & $75.9 \%$ & 0.64 & $61.6 \%$ & $78.7 \%$ & 0.5 \\
\hline
\end{tabular}
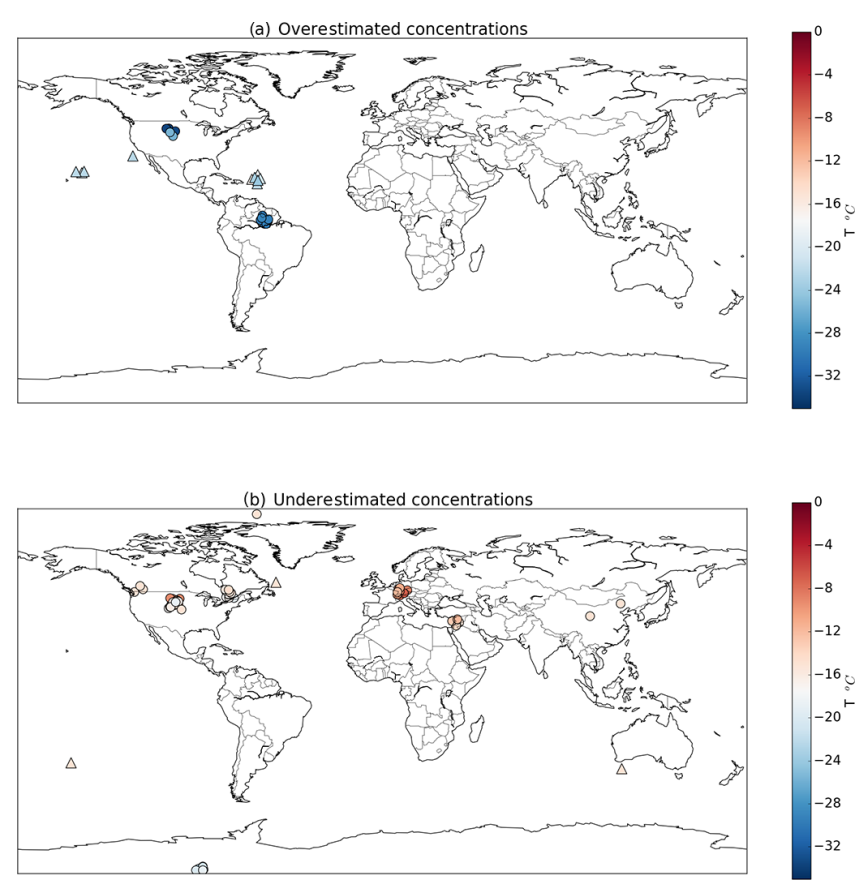

Figure 10. Overestimation and underestimation of places according to our two-species-based parameterization of INP (Atkinson et al., 2013; Wilson et al., 2015). (a) Shows the places where we overestimate the values of INPs by more than 1.5 orders of magnitude. (b) Similar to (a) but for places where the concentration is underestimated by more than 1.5 orders of magnitude. The location of the points have been moved randomly in the plot for purpose of visualization so it can be seen when the bias affects a single data point or a whole data set.

terrestrial emission sources. However, even over Northern Hemisphere regions influenced by dust, marine organic INP concentrations exceed K-feldspar INP concentrations on 10$30 \%$ of the days when the temperature is within the mixedphase range and the total concentration of INPs is larger than $10^{-4} \mathrm{~L}^{-1}$. Similarly, K-feldspar cannot be ruled out as an important source of INPs in the southern high latitudes because there are several days per month when the concentra- tion of transported K-feldspar INP dominates over the prevailing marine organics.

K-feldspar in our model can reproduce $70 \%$ of the observations of INPs in terrestrial locations at low temperatures $\left(T<-15^{\circ} \mathrm{C}\right)$ within 1.5 orders of magnitude. Because $\mathrm{K}$ feldspar is mainly a coarse aerosol type, it is scavenged more rapidly than the clay fraction of desert dusts, and therefore has substantially smaller influence on remote marine environments in contrast with Atkinson et al. (2013) where dust was not subject to wet removal. For remote locations, we find that marine organic aerosols acting as INPs are able to reproduce a majority $(80 \%)$ of the observations within an order of magnitude.

Our model of INPs based on emitted and transported aerosol species provides a reasonable explanation of measured global INP concentrations, but there are some important biases. The two-species model overestimates the concentrations of INPs in marine locations that are influenced by the transport of K-feldspar-containing dust particles by around 1.5 orders of magnitude, although it is difficult to draw firm conclusions from the small number of observations. Nevertheless, the bias points to the possible importance of missing processes, such as the effect of atmospheric processing of feldspar particles, a preferential scavenging of INPs as proposed in Stopelli et al. (2015), or a possible overestimation of the transport of this aerosol type. The model also underestimates measured INP concentrations at high temperatures in some terrestrial locations. This bias is most likely to be explained by neglecting the contribution of some terrestrial biogenic aerosol species such as soil dust, fungal spores and bacteria. The model bias is large at the surface, but some studies show that some of these species are not important for ice nucleation once in the atmosphere (Spracklen and Heald, 2014; Hoose et al., 2010a) because of their low simulated concentrations above the surface for heterogeneous ice nucleation. These species, however, could be important for triggering secondary production ice processes, such as the Hallett-Mossop process, due to its high nucleation temperatures. In addition, other unknown sources of ice-nucleating particles, such as biological fragments attached to mineral 
dust particles (O'Sullivan et al., 2015, 2016), could help explain underestimated INP concentrations in the model.

In summary, our results suggest that the inclusion of both marine organic and feldspar emissions are required to accurately simulate global INP concentrations. However, there are still large uncertainties to be resolved, such as the importance of acid coating affecting the INP ability of K-feldspar (Wex et al., 2014; Sullivan et al., 2010) or the relative importance of soot for ice nucleation in the atmosphere, which could lead to a possible anthropogenic effect on clouds.

Finally, we suggest that further experimental studies on the ice-nucleating ability of different aerosol species, followed by modelling studies of their importance in the atmosphere, will be crucial for determining the possible importance of other species for ice nucleation under atmospheric conditions. In addition, more INP measurements in the ambient atmosphere for different environments and seasons are necessary to better evaluate and constrain models. Among those, exploratory studies about the composition and type of icenucleating particles in terrestrial environments at high temperatures will be crucial to determine which species need to be included in models.

Data availability. The data used in this study can be accessed through the BACCHUS (http://www.bacchus-env.eu/in/info.php? $\mathrm{id}=71$ ) database of INP observations or by contacting the authors of the cited studies. 


\section{Appendix A: Marine organic emissions}

In order to represent the distribution of submicron marine organics aerosols, first we simulate the distribution of seasalt aerosols (SS) with GLOMAP mode for the year 2001. Then we look at the correlation between the monthly mean emission flux of sea-salt particles in the accumulation mode $(100 \mathrm{~nm}<r<1 \mu \mathrm{m})$ and the monthly mean surface concentration of submicron sea salt in the grid boxes corresponding to Mace Head and Amsterdam Island. We then take the grid boxes that score a correlation $R>0.9$ and assume that, as a first order approach, the emissions of these grid boxes will drive the concentrations of submicron sea spray in their corresponding stations (Fig. A1). Once these grid boxes are identified for every station, we calculate the organic mass fraction (OMF) in surface air (lowest model layer) at both stations with modelled concentrations of sea spray and measured concentrations of water insoluble organic matter (WIOM) following Eq. A1.

$\mathrm{OMF}=\frac{[\mathrm{WIOM}]}{\left[\mathrm{SS}_{\text {mass }}\right]+[\mathrm{WIOM}]}$

The WIOM in Mace Head data is obtained from Rinaldi et al. (2013) by averaging measurements corresponding to a few days (from 5 to 14 days) in every month. For Amsterdam island, WIOM is derived from Sciare et al. (2009) using a factor of 1.9 to convert from water insoluble organic carbon to WIOM (Burrows et al., 2013). The chlorophyll $a$ maps correspond to monthly mean values obtained from GLOBCOLOUR (Maritorena and Siegel, 2005), which made use of data from three different satellites to merge their chlorophyll $a$ maps and produce a final product with an enhanced global coverage.
In order to develop a parameterization of the organic mass fraction to be used in both hemispheres, we use the monthly mean values of the chlorophyll $a$ content in the grid boxes that were previously related to each station, together with the monthly mean reanalysis (ECMWF) wind speed at $10 \mathrm{~m}$ over the surface $(\mathrm{U} 10 \mathrm{M})$ of these grid boxes and relate these two variables to the organic mass fraction previously calculated (Fig. A2a). We then fit the OMF to a two-dimensional equation with the wind speed and chlorophyll $a$ content as variables (Fig. A2b). This gives us a parameterization of the OMF emitted with submicron sea spray that can fit our model. In order to avoid unrealistic OMF values due to extrapolation, we limit the maximum value of our OMF to 0.85 .

The mass flux of marine organic material can then be from the sea-salt flux following Eq. A5:

$$
\begin{aligned}
& \text { Flux }_{\text {total }}=\text { Flux }_{\text {SS }}+\text { Flux }_{\text {WIOM }} \\
& \text { Flux }_{\text {WIOM }}=\text { OMF } \cdot \text { Flux }_{\text {total }} \\
& \text { Flux }_{\text {total }}=\frac{\text { Flux }_{\text {WIOM }}}{\text { OMF }} \\
& \text { Flux }_{\text {WIOM }}=\frac{\text { Flux }_{\text {SS }} \cdot \text { OMF }}{1-\text { OMF }} .
\end{aligned}
$$


(a) Gridboxes influencing Mace Head

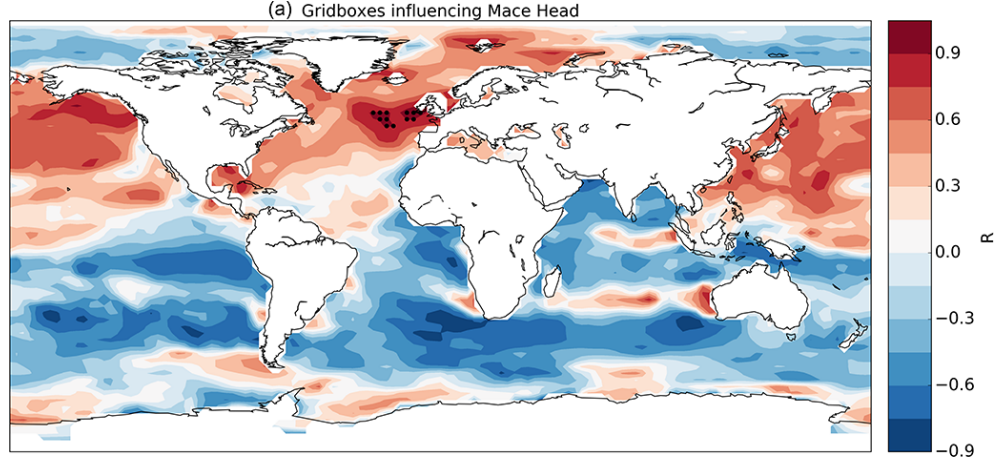

(b) Gridboxes influencing Amsterdam Island

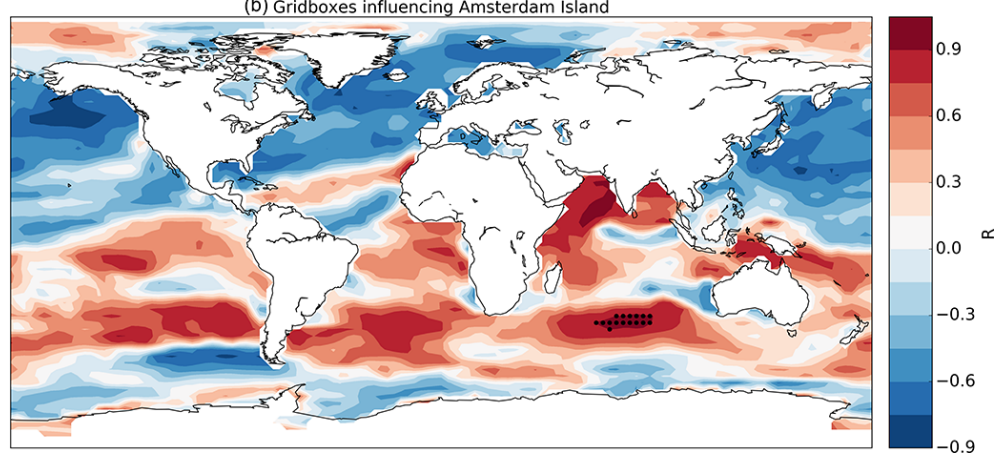

Figure A1. Linear correlation values between the monthly emission of submicron sea spray and their monthly concentrations in (a) Mace Head, (b) Amsterdam Island. The dots represent the grid boxes related to every station because they have a value $R>0.9$.
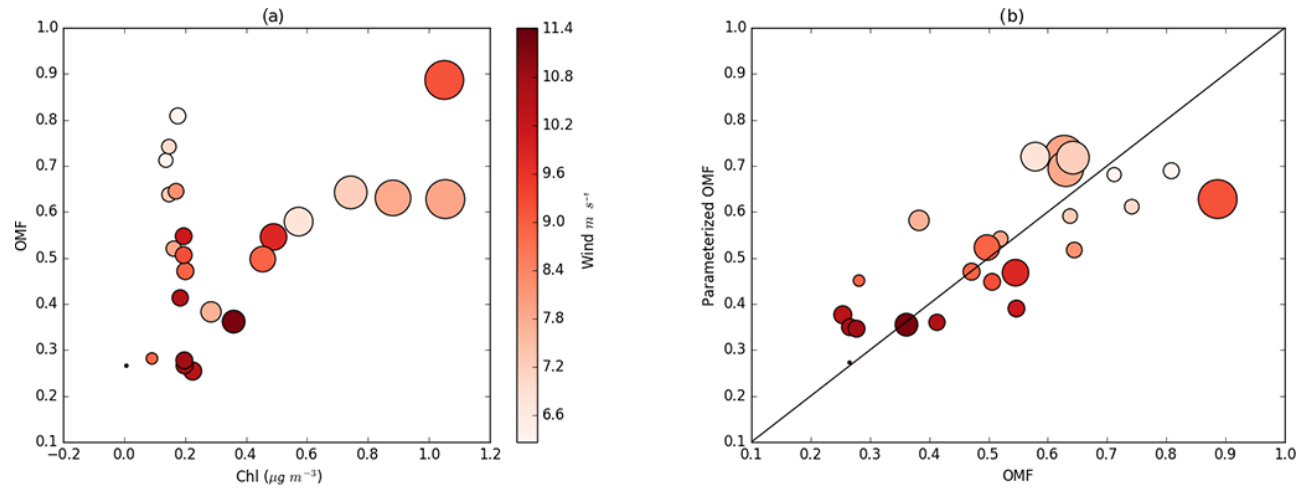

Figure A2. (a) OMF compared as a function of chlorophyll $a$ content and surface wind speed for the monthly mean values in both stations. The size of the points represent the mean chlorophyll $a$ content of the grid boxes related previously to every station (Fig. A1), the colour of the points is related to the wind speed of those grid boxes. Panel (b) shows the performance of the parameterization for reproducing the OMF calculated with the simulated concentration of submicron sea salt and the observed values of WIOM. The parameterization for the OMF is $\mathrm{OMF}=A \times\left[\mathrm{CHL}\left(\mathrm{mg} \mathrm{m}^{-3}\right)\right]+B \times\left[\mathrm{U} 10 \mathrm{M}\left(\mathrm{m} \mathrm{s}^{-1}\right)\right]^{C}+D$ with $A=0.241, B=-7.503, C=0.075, D=9.274$. 


\section{Appendix B: Calculation of INP concentrations}

Assuming that the active sites from which ice nucleation can occur under the singular description are randomly distributed in the aerosol population, the probability of one particle having a certain number of active sites $(k)$ can be represented by the Poisson distribution of Eq. B1.

$f(k, \lambda)=\frac{e^{-\lambda} \lambda^{k}}{k !}$

Here, $f$ is the probability of having $k$ active sites in a particle and $\lambda$ represents the expected value of active sites per particle at a certain temperature $(T)$. We can calculate the probability of a particle immersed in a supercooled water droplet to freeze it $(P)$ as the sum of the probabilities of having 1 or more active sites in Eq. B2:

$P=\sum_{k=1}^{\infty} f(k, \lambda)$

As the sum from $k=0$ to $k=\infty$ of Eq. B1 has to be equal to 1, we can also represent this sum as Eq. B3:

$P=\sum_{k=0}^{\infty} f(k, \lambda)-f(0, \lambda)=1-e^{-\lambda}$.

If we have a distribution of particles of the same size and same density of active sites, this probability $P$ will be the same for all of them, and so the fraction of supercooled water droplets that will freeze know as fraction frozen (ff), will therefore be

$\mathrm{ff}=1-e^{-\lambda}$.

We can then calculate the INP concentration as

$[\mathrm{INP}]=\mathrm{ff} \cdot[N]$,

where $[N]$ represents the concentration of a certain type of aerosol. For the case in which we have a density of active sites distributed across the surface area of a particle depending on temperature $n_{\mathrm{s}}(T)$, we can calculate $\lambda$ for a particle of radius $r$ as

$\lambda(r, T)=4 \pi r^{2} \cdot n_{\mathrm{S}}(T)$.

Hence,

$\mathrm{ff}(r, T)=1-e^{-n_{\mathrm{s}}(T) \cdot 4 \pi r^{2}}$.
In GLOMAP mode, the size distribution of aerosols is represented in log-normal modes, and their probability density function (PDF) is given by

$\operatorname{PDF}(r)=\frac{1}{r \cdot \ln (\sigma) \cdot \sqrt{2 \pi}} \cdot e^{\frac{-\left(\ln (r)-\ln \left(r_{m}\right)\right)^{2}}{2 \cdot \ln (\sigma)^{2}}}$,

where $r_{\mathrm{m}}$ is the mean radius of the mode and $\sigma$ the standard deviation of the mode.

The INP concentration is therefore the integral across all the possible values of $r$ for every mode, and it will change for every temperature:

$$
\begin{aligned}
{[\operatorname{INP}]_{\text {mode }}(T) } & =\int_{0}^{\infty}\left(1-e^{-4 \cdot \pi \cdot r^{2} \cdot n_{\mathrm{s}}(T)}\right) \\
& \cdot N \cdot \frac{1}{r \cdot \ln (\sigma) \cdot \sqrt{2 \pi}} \cdot e^{\frac{-\left(\ln (r)-\ln \left(r_{\mathrm{m}}\right)\right)^{2}}{2 \cdot \ln (\sigma)^{2}}} \mathrm{~d} r .
\end{aligned}
$$

In our case, we consider that just the soluble modes can activate into water droplets, so the total INP concentration is the sum of the concentrations for every soluble mode.

In the special case of having a value of $\lambda$ small $(\lambda<0.1)$, we can approximate the value of the fraction frozen (ff) using a first-order Taylor series centred in 0 :

$$
\begin{aligned}
& \mathrm{ff} \approx \mathrm{ff}_{\lambda=o}+\left.\frac{1}{1} \frac{\partial \mathrm{ff}}{\partial \lambda}\right|_{\lambda=0} \cdot \lambda+\ldots \\
& \mathrm{ff}_{\lambda=0}=1-e^{0}=0 \\
& \left.\frac{\partial \mathrm{ff}}{\partial \lambda}\right|_{\lambda=0}=\left[-e^{-\lambda} \cdot(-1)\right]_{\lambda=0} \cdot \lambda=1 \cdot \lambda \\
& \mathrm{ff} \approx \lambda .
\end{aligned}
$$

In other words, if the number of active sites is small compared with the number of particles, we can approximate the number of particles having one or more actives sites, to the number of active sites. And the INP concentration can be calculated as follows:

$[\operatorname{INP}](T) \approx \lambda(T) \cdot[N]$.

\section{Appendix C: INP data set}

The data set used in this study is a compilation of published and unpublished data provided by different groups contributing to the BACCHUS data set of INPs (http://www. bacchus-env.eu/in/index.php). Table $\mathrm{C} 1$ shows a summary of the data sets. We note that a study from Bigg (1996) reported INP concentrations in the high Arctic. We could not include it in our database as the exact locations could not be obtained. However we note that the range of concentrations reported by 
Table C1. Table of the data sets used for this study.

\begin{tabular}{lllll}
\hline Campaign/data set & Location & Marine or terrestrial & Data points & References \\
\hline Bigg73 & Australia & Terrestrial & 24 & Bigg (1973) \\
CLEX & Eastern Canada & Terrestrial & 60 & DeMott et al. (2010) \\
Yin & China & Terrestrial & 21 & Yin et al. (2012) \\
ICE-L_Ambient & Central USA & Terrestrial & 31 & DeMott et al. (2010) \\
DeMott2016 & Marine locations & Marine & 44 & DeMott et al. (2016) \\
Conen_JFJ & Jungfraujoch & Terrestrial & 6 & BACCHUS Conen et al. (2015) \\
Mason2016 terrestrial & Terrestrial locations & Terrestrial & 15 & Mason et al. (2016) \\
KAD_South_Pole & South Pole & Terrestrial & 8 & BACCHUS Ardon-Dryer et al. (2011) \\
ICE-LCVI & Central USA & Terrestrial & 27 & DeMott et al. (2010) \\
Rosisnky & Gulf of Mexico & Marine & 5 & Rosinski et al. (1988) \\
Bigg1973 & Southern Ocean & Marine & 102 & Bigg (1973) \\
Conen_chaumont & Chaumont & Terrestrial & 7 & BACCHUS Conen et al. (2015) \\
AMAZE-08 & Amazon rainforest & Terrestrial & 63 & DeMott et al. (2010) \\
INSPECT-I & Central USA & Terrestrial & 13 & DeMott et al. (2010) \\
Mason2016 Marine & Marine locations & Marine & 6 & Mason et al. (2016) \\
KAD_Israel & Jerusalem & Terrestrial & 16 & BACCHUS Ardon-Dryer and Levin (2014) \\
INSPECT-II & Central USA & Terrestrial & 11 & DeMott et al. (2010) \\
\hline
\end{tabular}

Bigg (1996) (from 13 to $2.9 \mathrm{~m}^{-3}$ at $-15^{\circ} \mathrm{C}$ ) are close to our simulated values using feldspar and marine organics (from 7.4 to $0.1 \mathrm{~m}^{-3}$ ) during the months of the campaign (August to October). The data sets obtained through the BACCHUS project database are labelled "BACCHUS" in Table C1. The data sets corresponding to long-term measurements in a single location were resized to account for a single data point at every temperature. This is done in order to avoid statistical overweighting of a single location or campaign. 
Competing interests. The authors declare that they have no conflict of interest.

Acknowledgements. This study has been funded by the European Union' Seventh Framework Programme (FP7/2007-797 2013) under grant agreement no. 603445 (BACCHUS), the European Research Council (ERC, 240449 ICE and 648661 MarineIce) and the National Environmental Research Council, (NERC, NE/I013466/1; $\mathrm{NE} / \mathrm{K} 004417 / 1)$. The global model simulations were performed on the ARCHER UK National Supercomputing Service. We acknowledge Franz Conen and Christoph Huglin who contributed data used in this paper. Ken S. Carslaw is a Royal Society Wolfson Merit Award holder. Paul DeMott acknowledges support from the US National Science Foundation grant AGS1358495. Susannah Burrows was supported as part of the Accelerated Climate Modeling for Energy (ACME) project, funded by the US Department of Energy, Office of Science, Office of Biological and Environmental Research. We thank Katty Huang, Luisa Ickes and Ulrike Lohmann for useful discussions on modelling marine organic aerosols.

Edited by: C. Hoose

Reviewed by: two anonymous referees

\section{References}

Aller, J. Y., Kuznetsova, M. R., Jahns, C. J., and Kemp, P. F.: The sea surface microlayer as a source of viral and bacterial enrichment in marine aerosols, J. Aerosol Sci., 36, 801-812, doi:10.1016/j.jaerosci.2004.10.012, 2005.

Alpert, P. A., Aller, J. Y., and Knopf, D. A.: Ice nucleation from aqueous $\mathrm{NaCl}$ droplets with and without marine diatoms, Atmos. Chem. Phys., 11, 5539-5555, doi:10.5194/acp-11-55392011, 2011.

Ardon-Dryer, K. and Levin, Z.: Ground-based measurements of immersion freezing in the eastern Mediterranean, Atmos. Chem. Phys., 14, 5217-5231, doi:10.5194/acp-14-5217-2014, 2014.

Ardon-Dryer, K., Levin, Z., and Lawson, R. P.: Characteristics of immersion freezing nuclei at the South Pole station in Antarctica, Atmos. Chem. Phys., 11, 4015-4024, doi:10.5194/acp-11-40152011, 2011.

Atkinson, J. D., Murray, B. J., Woodhouse, M. T., Whale, T. F., Baustian, K. J., Carslaw, K. S., Dobbie, S., O'Sullivan, D., and Malkin, T. L.: The importance of feldspar for ice nucleation by mineral dust in mixed-phase clouds, Nature, 498, 355-358, doi:10.1038/nature12278, 2013.

Augustin-Bauditz, S., Wex, H., Kanter, S., Ebert, M., Niedermeier, D., Stolz, F., Prager, A., and Stratmann, F.: The immersion mode ice nucleation behavior of mineral dusts: A comparison of different pure and surface modified dusts, Geophys. Res. Lett., 41, 7375-7382, doi:10.1002/2014GL061317, 2014.

Bauer, P., Thorpe, A., and Brunet, G.: The quiet revolution of numerical weather prediction, Nature, 525, 47-55, doi:10.1038/nature14956, 2015.

Bigg, E. K.: Ice Nucleus Concentrations in Remote Areas, J. Atmos. Sci., 30, 1153-1157, doi:10.1175/15200469(1973)030<1153:INCIRA>2.0.CO;2, 1973.
Bigg, E. K.: Ice forming nuclei in the high Arctic, Tellus B, 48, 223-233, doi:10.1034/j.1600-0889.1996.t01-1-00007.x, 1996.

Bodas-Salcedo, A., Williams, K. D., Ringer, M. A., Beau, I., Cole, J. N. S., Dufresne, J. L., Koshiro, T., Stevens, B., Wang, Z., and Yokohata, T.: Origins of the solar radiation biases over the Southern Ocean in CFMIP2 models, J. Climate, 27, 41-56, doi:10.1175/JCLI-D-13-00169.1, 2014.

Boose, Y., Sierau, B., García, M. I., Rodríguez, S., Alastuey, A., Linke, C., Schnaiter, M., Kupiszewski, P., Kanji, Z. A., and Lohmann, U.: Ice nucleating particles in the Saharan Air Layer, Atmos. Chem. Phys., 16, 9067-9087, doi:10.5194/acp-16-90672016, 2016.

Broadley, S. L., Murray, B. J., Herbert, R. J., Atkinson, J. D., Dobbie, S., Malkin, T. L., Condliffe, E., and Neve, L.: Immersion mode heterogeneous ice nucleation by an illite rich powder representative of atmospheric mineral dust, Atmos. Chem. Phys., 12, 287-307, doi:10.5194/acp-12-287-2012, 2012.

Browse, J., Carslaw, K. S., Arnold, S. R., Pringle, K., and Boucher, O.: The scavenging processes controlling the seasonal cycle in Arctic sulphate and black carbon aerosol, Atmos. Chem. Phys., 12, 6775-6798, doi:10.5194/acp-12-6775-2012, 2012.

Burrows, S. M., Hoose, C., Pöschl, U., and Lawrence, M. G.: Ice nuclei in marine air: biogenic particles or dust?, Atmos. Chem. Phys., 13, 245-267, doi:10.5194/acp-13-245-2013, 2013.

Carslaw, K. S., Lee, L. A., Reddington, C. L., Pringle, K. J., Rap, A., Forster, P. M., Mann, G. W., Spracklen, D. V., Woodhouse, M. T., Regayre, L. A., and Pierce, J. R.: Large contribution of natural aerosols to uncertainty in indirect forcing., Nature, 503, 67-71, doi:10.1038/nature12674, 2013.

Choi, Y.-S., Lindzen, R. S., Ho, C.-H., and Kim, J.: Space observations of cold-cloud phase change, P. Natl. Acad. Sci. USA, 107, 11211-11216, doi:10.1073/pnas.1006241107, 2010.

Claquin, T., Schulz, M., and Balkanski, Y. J.: Modeling the mineralogy of atmospheric dust sources, J. Geophys. Res., 104, 22243, doi:10.1029/1999JD900416, 1999.

Cochran, R. E., Jayarathne, T., Stone, E. A., and Grassian, V. H.: Selectivity Across the Interface: A Test of Surface Activity in the Composition of Organic-Enriched Aerosols from Bubble Bursting, J. Phys. Chem. Lett., 7, 1692-1696, doi:10.1021/acs.jpclett.6b00489, 2016.

Conen, F., Rodríguez, S., Hüglin, C., Henne, S., Herrmann, E., Bukowiecki, N., and Alewell, C.: Atmospheric ice nuclei at the high-altitude observatory Jungfraujoch, Switzerland, Tellus B, 67, 1-10, doi:10.3402/tellusb.v67.25014, 2015.

Cunliffe, M., Engel, A., Frka, S., Gašparović, B., Guitart, C., Murrell, J. C., Salter, M., Stolle, C., Upstill-Goddard, R., and Wurl, O.: Sea surface microlayers: A unified physicochemical and biological perspective of the air ocean interface, Prog. Oceanogr., 109, 104-116, doi:10.1016/j.pocean.2012.08.004, 2013.

DeMott, P. J., Prenni, A. J., Liu, X., Kreidenweis, S. M., Petters, M. D., Twohy, C. H., Richardson, M. S., Eidhammer, T., and Rogers, D. C.: Predicting global atmospheric ice nuclei distributions and their impacts on climate, P. Natl. Acad. Sci. USA, 107, 11217-11222, doi:10.1073/pnas.0910818107, 2010.

DeMott, P. J., Prenni, A. J., McMeeking, G. R., Sullivan, R. C., Petters, M. D., Tobo, Y., Niemand, M., Möhler, O., Snider, J. R., Wang, Z., and Kreidenweis, S. M.: Integrating laboratory and field data to quantify the immersion freezing ice nucleation activ- 
ity of mineral dust particles, Atmos. Chem. Phys., 15, 393-409, doi:10.5194/acp-15-393-2015, 2015.

DeMott, P. J., Hill, T. C., McCluskey, C. S., Prather, K. A., Collins, D. B., Sullivan, R. C., Ruppel, M. J., Mason, R. H., Irish, V. E., Lee, T., et al.: Sea spray aerosol as a unique source of ice nucleating particles, P. Natl. Acad. Sci. USA, 113, 5797-5803, 2016.

Dentener, F., Kinne, S., Bond, T., Boucher, O., Cofala, J., Generoso, S., Ginoux, P., Gong, S., Hoelzemann, J. J., Ito, A., Marelli, L., Penner, J. E., Putaud, J.-P., Textor, C., Schulz, M., van der Werf, G. R., and Wilson, J.: Emissions of primary aerosol and precursor gases in the years 2000 and 1750 prescribed data-sets for AeroCom, Atmos. Chem. Phys., 6, 4321-4344, doi:10.5194/acp-64321-2006, 2006.

Eidhammer, T., DeMott, P. J., and Kreidenweis, S. M.: A comparison of heterogeneous ice nucleation parameterizations using a parcel model framework, J. Geophys. Res., 114, D06202, doi:10.1029/2008JD011095, 2009.

Emersic, C., Connolly, P. J., Boult, S., Campana, M., and Li, Z.: Investigating the discrepancy between wet-suspension- and drydispersion-derived ice nucleation efficiency of mineral particles, Atmos. Chem. Phys., 15, 11311-11326, doi:10.5194/acp15-11311-2015, 2015.

Facchini, M. C., Rinaldi, M., Decesari, S., Carbone, C., Finessi, E., Mircea, M., Fuzzi, S., Ceburnis, D., Flanagan, R., Nilsson, E. D., de Leeuw, G., Martino, M., Woeltjen, J., and O'Dowd, C. D.: Primary submicron marine aerosol dominated by insoluble organic colloids and aggregates, Geophys. Res. Lett., 35, L17814, doi:10.1029/2008GL034210, 2008.

Fall, R. and Schnell, R. C.: Association of an icenucleating pseudomonad with cultures of the marine dinoflagellate, Heterocapsa niei, Mar. Res., 43, 257-265, doi:10.1357/002224085788437370, 1985.

Field, P. R., Heymsfield, A. J., Shipway, B. J., DeMott, P. J., Pratt, K. A., Rogers, D. C., Stith, J., and Prather, K. A.: Ice in Clouds Experiment Layer Clouds. Part II: Testing Characteristics of Heterogeneous Ice Formation in Lee Wave Clouds, J. Atmos. Sci., 69, 1066-1079, doi:10.1175/JAS-D-11-026.1, 2012.

Fröhlich-Nowoisky, J., Hill, T. C. J., Pummer, B. G., Yordanova, P., Franc, G. D., and Pöschl, U.: Ice nucleation activity in the widespread soil fungus Mortierella alpina, Biogeosciences, 12, 1057-1071, doi:10.5194/bg-12-1057-2015, 2015.

Fuentes, E., Coe, H., Green, D., and McFiggans, G.: On the impacts of phytoplankton-derived organic matter on the properties of the primary marine aerosol - Part 2: Composition, hygroscopicity and cloud condensation activity, Atmos. Chem. Phys., 11, 25852602, doi:10.5194/acp-11-2585-2011, 2011.

Gantt, B., Meskhidze, N., Facchini, M. C., Rinaldi, M., Ceburnis, D., and O'Dowd, C. D.: Wind speed dependent size-resolved parameterization for the organic mass fraction of sea spray aerosol, Atmos. Chem. Phys., 11, 8777-8790, doi:10.5194/acp-11-87772011, 2011.

Garcia, E., Hill, T. C. J., Prenni, A. J., DeMott, P. J., Franc, G. D., and Kreidenweis, S. M.: Biogenic ice nuclei in boundary layer air over two U.S. High Plains agricultural regions, J. Geophys. Res.-Atmos., 117, D18209, doi:10.1029/2012JD018343, 2012.

Ghan, S. J. and Schwartz, S. E.: Aerosol Properties and Processes: A Path from Field and Laboratory Measurements to Global Climate Models, B. Am. Meteorol. Soc., 88, 1059-1083, doi:10.1175/BAMS-88-7-1059, 2007.
Gong, S. L.: A parameterization of sea-salt aerosol source function for sub- and super-micron particles, Global Biogeochem. Cy., 17, 1097, doi:10.1029/2003GB002079, 2003.

Haga, D. I., Burrows, S. M., Iannone, R., Wheeler, M. J., Mason, R. H., Chen, J., Polishchuk, E. A., Pöschl, U., and Bertram, A. K.: Ice nucleation by fungal spores from the classes Agaricomycetes, Ustilaginomycetes, and Eurotiomycetes, and the effect on the atmospheric transport of these spores, Atmos. Chem. Phys., 14, 8611-8630, doi:10.5194/acp-14-8611-2014, 2014.

Haga, D. I., Iannone, R., Wheeler, M. J., Mason, R., Polishchuk, E. A., Fetch, T., Van Der Kamp, B. J., McKendry, I. G., and Bertram, A. K.: Ice nucleation properties of rust and bunt fungal spores and their transport to high altitudes, where they can cause heterogeneous freezing, J. Geophys. Res.-Atmos., 118, 72607272, doi:10.1002/jgrd.50556, 2013.

Hallett, J. and Mossop, S. C.: Production of secondary ice particles during the riming process, Nature, doi:10.1038/249026a0, 1974.

Harrison, A. D., Whale, T. F., Carpenter, M. A., Holden, M. A., Neve, L., O'Sullivan, D., Vergara Temprado, J., and Murray, B. J.: Not all feldspars are equal: a survey of ice nucleating properties across the feldspar group of minerals, Atmos. Chem. Phys., 16, 10927-10940, doi:10.5194/acp-16-10927-2016, 2016.

Hartmann, S., Augustin, S., Clauss, T., Wex, H., Šantl-Temkiv, T., Voigtländer, J., Niedermeier, D., and Stratmann, F.: Immersion freezing of ice nucleation active protein complexes, Atmos. Chem. Phys., 13, 5751-5766, doi:10.5194/acp-13-57512013, 2013.

Herbert, R. J., Murray, B. J., Whale, T. F., Dobbie, S. J., and Atkinson, J. D.: Representing time-dependent freezing behaviour in immersion mode ice nucleation, Atmos. Chem. Phys., 14, 85018520, doi:10.5194/acp-14-8501-2014, 2014.

Herbert, R. J., Murray, B. J., Dobbie, S. J., and Koop, T.: Sensitivity of liquid clouds to homogenous freezing parameterizations, Geophys. Res. Lett., 42, 1599-1605, doi:10.1002/2014GL062729, 2015.

Hoose, C. and Möhler, O.: Heterogeneous ice nucleation on atmospheric aerosols: a review of results from laboratory experiments, Atmos. Chem. Phys., 12, 9817-9854, doi:10.5194/acp-12-98172012, 2012.

Hoose, C., Kristjánsson, J. E., and Burrows, S. M.: How important is biological ice nucleation in clouds on a global scale?, Environ. Res. Lett., doi:10.1088/1748-9326/5/2/024009, 2010a.

Hoose, C., Kristjánsson, J. E., Chen, J.-P., and Hazra, A.: A Classical-Theory-Based Parameterization of Heterogeneous Ice Nucleation by Mineral Dust, Soot, and Biological Particles in a Global Climate Model, J. Atmos. Sci., 67, 2483-2503, doi:10.1175/2010JAS3425.1, 2010b.

Huneeus, N., Schulz, M., Balkanski, Y., Griesfeller, J., Prospero, J., Kinne, S., Bauer, S., Boucher, O., Chin, M., Dentener, F., Diehl, T., Easter, R., Fillmore, D., Ghan, S., Ginoux, P., Grini, A., Horowitz, L., Koch, D., Krol, M. C., Landing, W., Liu, X., Mahowald, N., Miller, R., Morcrette, J.-J., Myhre, G., Penner, J., Perlwitz, J., Stier, P., Takemura, T., and Zender, C. S.: Global dust model intercomparison in AeroCom phase I, Atmos. Chem. Phys., 11, 7781-7816, doi:10.5194/acp-11-7781-2011, 2011.

Knopf, D. A., Alpert, P. A., Wang, B., and Aller, J. Y.: Stimulation of ice nucleation by marine diatoms, Nat. Geosci., 4, 88-90, doi:10.1038/ngeo1037, 2010. 
Kodros, J. K., Scott, C. E., Farina, S. C., Lee, Y. H., L'Orange, C., Volckens, J., and Pierce, J. R.: Uncertainties in global aerosols and climate effects due to biofuel emissions, Atmos. Chem. Phys., 15, 8577-8596, doi:10.5194/acp-15-8577-2015, 2015.

Koehler, K. A., Kreidenweis, S. M., DeMott, P. J., Petters, M. D., Prenni, A. J., and Möhler, O.: Laboratory investigations of the impact of mineral dust aerosol on cold cloud formation, Atmos. Chem. Phys., 10, 11955-11968, doi:10.5194/acp10-11955-2010, 2010.

Korolev, A.: Limitations of the Wegener-Bergeron-Findeisen Mechanism in the Evolution of Mixed-Phase Clouds, J. Atmos. Sci., 64, 3372-3375, doi:10.1175/JAS4035.1, 2007.

Lafon, S., Rajot, J. L., Alfaro, S. C., and Gaudichet, A.: Quantification of iron oxides in desert aerosol, Atmos. Environ., 38, 12111218, doi:10.1016/j.atmosenv.2003.11.006, 2004.

Lohmann, U. and Diehl, K.: Sensitivity studies of the importance of dust ice nuclei for the indirect aerosol effect on stratiform mixed-phase clouds, J. Atmos. Sci., 63, 968-982, doi:10.1175/JAS3662.1, 2006.

Maki, L. R. and Willoughby, K. J.: Bacteria as Biogenic Sources of Freezing Nuclei, J. Appl. Meteorol., 17, 1049-1053, doi:10.1175/1520-0450(1978)017<1049:BABSOF>2.0.CO;2, 1978.

Mann, G. W., Carslaw, K. S., Spracklen, D. V., Ridley, D. A., Manktelow, P. T., Chipperfield, M. P., Pickering, S. J., and Johnson, C. E.: Description and evaluation of GLOMAP-mode: a modal global aerosol microphysics model for the UKCA composition-climate model, Geosci. Model Dev., 3, 519-551, doi:10.5194/gmd-3-519-2010, 2010.

Mann, G. W., Carslaw, K. S., Reddington, C. L., Pringle, K. J., Schulz, M., Asmi, A., Spracklen, D. V., Ridley, D. A., Woodhouse, M. T., Lee, L. A., Zhang, K., Ghan, S. J., Easter, R. C., Liu, X., Stier, P., Lee, Y. H., Adams, P. J., Tost, H., Lelieveld, J., Bauer, S. E., Tsigaridis, K., van Noije, T. P. C., Strunk, A., Vignati, E., Bellouin, N., Dalvi, M., Johnson, C. E., Bergman, T., Kokkola, H., von Salzen, K., Yu, F., Luo, G., Petzold, A., Heintzenberg, J., Clarke, A., Ogren, J. A., Gras, J., Baltensperger, U., Kaminski, U., Jennings, S. G., O’Dowd, C. D., Harrison, R. M., Beddows, D. C. S., Kulmala, M., Viisanen, Y., Ulevicius, V., Mihalopoulos, N., Zdimal, V., Fiebig, M., Hansson, H.-C., Swietlicki, E., and Henzing, J. S.: Intercomparison and evaluation of global aerosol microphysical properties among AeroCom models of a range of complexity, Atmos. Chem. Phys., 14, 4679-4713, doi:10.5194/acp-14-4679-2014, 2014.

Marcolli, C., Gedamke, S., Peter, T., and Zobrist, B.: Efficiency of immersion mode ice nucleation on surrogates of mineral dust, Atmos. Chem. Phys., 7, 5081-5091, doi:10.5194/acp-7-50812007, 2007.

Maritorena, S. and Siegel, D. A.: Consistent merging of satellite ocean color data sets using a bio-optical model, Remote Sens. Environ., 94, 429-440, doi:10.1016/j.rse.2004.08.014, 2005.

Mason, R. H., Si, M., Chou, C., Irish, V. E., Dickie, R., Elizondo, P., Wong, R., Brintnell, M., Elsasser, M., Lassar, W. M., Pierce, K. M., Leaitch, W. R., MacDonald, A. M., Platt, A., Toom-Sauntry, D., Sarda-Estève, R., Schiller, C. L., Suski, K. J., Hill, T. C. J., Abbatt, J. P. D., Huffman, J. A., DeMott, P. J., and Bertram, A. K.: Size-resolved measurements of ice-nucleating particles at six locations in North America and one in Europe, Atmos. Chem. Phys., 16, 1637-1651, doi:10.5194/acp-16-1637-2016, 2016.
McCoy, D. T., Hartmann, D. L., Zelinka, M. D., Ceppi, P., and Grosvenor, D. P.: Mixed-phase cloud physics and Southern Ocean cloud feedback in climate models, J. Geophys. Res.Atmos., 120, 9539-9554, doi:10.1002/2015JD023603, 2015.

Meyers, M. P., DeMott, P. J., and Cotton, W. R.: New Primary Ice-Nucleation Parameterizations in an Explicit Cloud Model, J. Appl. Meteorol., 31, 708-721, doi:10.1175/15200450(1992)031<0708:NPINPI>2.0.CO;2, 1992.

Möhler, O., Georgakopoulos, D. G., Morris, C. E., Benz, S., Ebert, V., Hunsmann, S., Saathoff, H., Schnaiter, M., and Wagner, R.: Heterogeneous ice nucleation activity of bacteria: new laboratory experiments at simulated cloud conditions, Biogeosciences, 5, 1425-1435, doi:10.5194/bg-5-1425-2008, 2008.

Monahan, E. C., Spiel, D. E., and Davidson, K. L.: A Model of Marine Aerosol Generation Via Whitecaps and Wave Disruption, Springer Netherlands, Dordrecht, 167-174, doi:10.1007/978-94009-4668-2_16, 1986.

Morris, C. E., Sands, D. C., Glaux, C., Samsatly, J., Asaad, S., Moukahel, A. R., Gonçalves, F. L. T., and Bigg, E. K.: Urediospores of rust fungi are ice nucleation active at $>-10{ }^{\circ} \mathrm{C}$ and harbor ice nucleation active bacteria, Atmos. Chem. Phys., 13, 4223-4233, doi:10.5194/acp-13-4223-2013, 2013.

Morrison, H., de Boer, G., Feingold, G., Harrington, J., Shupe, M. D., and Sulia, K.: Resilience of persistent Arctic mixed-phase clouds, Nat. Geosci., 5, 11-17, doi:10.1038/ngeo1332, 2011.

Murphy, D. M. and Koop, T.: Review of the vapour pressures of ice and supercooled water for atmospheric applications, Q. J. Roy. Meteorol. Soc., 131, 1539-1565, doi:10.1256/qj.04.94, 2005.

Murray, B. J., Broadley, S. L., Wilson, T. W., Atkinson, J. D., and Wills, R. H.: Heterogeneous freezing of water droplets containing kaolinite particles, Atmos. Chem. Phys., 11, 4191-4207, doi:10.5194/acp-11-4191-2011, 2011.

Murray, B. J., O’Sullivan, D., Atkinson, J. D., and Webb, M. E.: Ice nucleation by particles immersed in supercooled cloud droplets, Chem. Soc. Rev., 41, 6519, doi:10.1039/c2cs35200a, 2012.

Nickovic, S., Vukovic, A., Vujadinovic, M., Djurdjevic, V., and Pejanovic, G.: Technical Note: High-resolution mineralogical database of dust-productive soils for atmospheric dust modeling, Atmos. Chem. Phys., 12, 845-855, doi:10.5194/acp-12-8452012, 2012.

Niedermeier, D., Shaw, R. A., Hartmann, S., Wex, H., Clauss, T., Voigtländer, J., and Stratmann, F.: Heterogeneous ice nucleation: exploring the transition from stochastic to singular freezing behavior, Atmos. Chem. Phys., 11, 8767-8775, doi:10.5194/acp11-8767-2011, 2011.

Niedermeier, D., Augustin-bauditz, S., Hartmann, S., Wex, H., and Stratmann, F.: Can we define an asymptotic value for the ice active surface site density for heterogeneous ice nucleation ?, J. Geophys. Res.-Atmos., 120, 5036-5046, doi:10.1002/2014JD022814, 2015.

Niemand, M., Möhler, O., Vogel, B., Vogel, H., Hoose, C., Connolly, P., Klein, H., Bingemer, H., DeMott, P., Skrotzki, J., and Leisner, T.: A Particle-Surface-Area-Based Parameterization of Immersion Freezing on Desert Dust Particles, J. Atmos. Sci., 69, 3077-3092, doi:10.1175/JAS-D-11-0249.1, 2012.

O’Dowd, C., Ceburnis, D., Ovadnevaite, J., Bialek, J., Stengel, D. B., Zacharias, M., Nitschke, U., Connan, S., Rinaldi, M., Fuzzi, S., Decesari, S., Cristina Facchini, M., Marullo, S., Santoleri, R., Dell' Anno, A., Corinaldesi, C., Tangherlini, M., and 
Danovaro, R.: Connecting marine productivity to sea-spray via nanoscale biological processes: Phytoplankton Dance or Death Disco?, Sci. Rep., 5, 14883, doi:10.1038/srep14883, 2015.

Orellana, M. V., Matrai, P. A., Leck, C., Rauschenberg, C. D., Lee, A. M., and Coz, E.: Marine microgels as a source of cloud condensation nuclei in the high Arctic, P. Natl. Acad. Sci. USA, 108, 13612-13617, doi:10.1073/pnas.1102457108, 2011.

O’Sullivan, D., Murray, B. J., Malkin, T. L., Whale, T. F., Umo, N. S., Atkinson, J. D., Price, H. C., Baustian, K. J., Browse, J., and Webb, M. E.: Ice nucleation by fertile soil dusts: relative importance of mineral and biogenic components, Atmos. Chem. Phys., 14, 1853-1867, doi:10.5194/acp-14-1853-2014, 2014.

O’Sullivan, D., Murray, B. J., Ross, J. F., Whale, T. F., Price, H. C., Atkinson, J. D., Umo, N. S., and Webb, M. E.: The relevance of nanoscale biological fragments for ice nucleation in clouds, Sci. Rep., 5, 8082, doi:10.1038/srep08082, 2015.

O'Sullivan, D., Murray, B. J., Ross, J. F., and Webb, M. E.: The adsorption of fungal ice-nucleating proteins on mineral dusts: a terrestrial reservoir of atmospheric ice-nucleating particles, Atmos. Chem. Phys., 16, 7879-7887, doi:10.5194/acp-16-78792016, 2016.

Ovadnevaite, J., O’Dowd, C., Dall'Osto, M., Ceburnis, D., Worsnop, D. R., and Berresheim, H.: Detecting high contributions of primary organic matter to marine aerosol: A case study, Geophys. Res. Lett., 38, L02807, doi:10.1029/2010GL046083, 2011.

Partanen, A.-I., Dunne, E. M., Bergman, T., Laakso, A., Kokkola, H., Ovadnevaite, J., Sogacheva, L., Baisnée, D., Sciare, J., Manders, A., O'Dowd, C., de Leeuw, G., and Korhonen, H.: Global modelling of direct and indirect effects of sea spray aerosol using a source function encapsulating wave state, Atmos. Chem. Phys., 14, 11731-11752, doi:10.5194/acp-14-11731-2014, 2014.

Perlwitz, J. P., Pérez García-Pando, C., and Miller, R. L.: Predicting the mineral composition of dust aerosols - Part 1: Representing key processes, Atmos. Chem. Phys., 15, 11593-11627, doi:10.5194/acp-15-11593-2015, 2015.

Pouleur, S., Richard, C., Martin, J., and Antoun, H.: Ice nucleation activity in Fusarium acuminatum and Fusarium avenaceum, Appl. Environ. Microbiol., 58, 2960-2964, 1992.

Pummer, B. G., Budke, C., Augustin-Bauditz, S., Niedermeier, D., Felgitsch, L., Kampf, C. J., Huber, R. G., Liedl, K. R., Loerting, T., Moschen, T., Schauperl, M., Tollinger, M., Morris, C. E., Wex, H., Grothe, H., Pöschl, U., Koop, T., and FröhlichNowoisky, J.: Ice nucleation by water-soluble macromolecules, Atmos. Chem. Phys., 15, 4077-4091, doi:10.5194/acp-15-40772015, 2015.

Quinn, P. K., Bates, T. S., Schulz, K. S., Coffman, D. J., Frossard, A. A., Russell, L. M., Keene, W. C., and Kieber, D. J.: Contribution of sea surface carbon pool to organic matter enrichment in sea spray aerosol, Nat. Geosci., 7, 228-232, doi:10.1038/ngeo2092, 2014.

Rap, A., Scott, C. E., Spracklen, D. V., Bellouin, N., Forster, P. M., Carslaw, K. S., Schmidt, A., and Mann, G.: Natural aerosol direct and indirect radiative effects, Geophys. Res. Lett., 40, $3297-$ 3301, doi:10.1002/grl.50441, 2013.

Riechers, B., Wittbracht, F., Hütten, A., and Koop, T.: The homogeneous ice nucleation rate of water droplets produced in a microfluidic device and the role of temperature uncertainty, Phys. Chem. Chem. Phys., 15, 5873, doi:10.1039/c3cp42437e, 2013.
Rinaldi, M., Fuzzi, S., Decesari, S., Marullo, S., Santoleri, R., Provenzale, A., von Hardenberg, J., Ceburnis, D., Vaishya, A., O'Dowd, C. D., and Facchini, M. C.: Is chlorophyll- a the best surrogate for organic matter enrichment in submicron primary marine aerosol?, J. Geophys. Res.-Atmos., 118, 49644973, doi:10.1002/jgrd.50417, 2013.

Rosenfeld, D., Yu, X., Liu, G., Xu, X., Zhu, Y., Yue, Z., Dai, J., Dong, Z., Dong, Y., and Peng, Y.: Glaciation temperatures of convective clouds ingesting desert dust, air pollution and smoke from forest fires, Geophys. Res. Lett., 38, L21804, doi:10.1029/2011GL049423, 2011.

Rosinski, J., Haagenson, P., Nagamoto, C., and Parungo, F.: Iceforming nuclei of maritime origin, J. Aerosol Sci., 17, 23-46, doi:10.1016/0021-8502(86)90004-2, 1986.

Rosinski, J., Haagenson, P., Nagamoto, C., and Parungo, F.: Nature of ice-forming nuclei in marine air masses, J. Aerosol Sci., 18, 291-309, doi:10.1016/0021-8502(87)90024-3, 1987.

Rosinski, J., Haagenson, P., Nagamoto, C., Quintana, B., Parungo, F., and Hoyt, S.: Ice-forming nuclei in air masses over the Gulf of Mexico, J. Aerosol Sci., 19, 539-551, doi:10.1016/00218502(88)90206-6, 1988.

Russell, L. M., Hawkins, L. N., Frossard, A. A., Quinn, P. K., and Bates, T. S.: Carbohydrate-like composition of submicron atmospheric particles and their production from ocean bubble bursting, P. Natl. Acad. Sci. USA, 107, 6652-6657, doi:10.1073/pnas.0908905107, 2010.

Savre, J. and Ekman, A. M. L.: A theory-based parameterization for heterogeneous ice nucleation and implications for the simulation of ice processes in atmospheric models, J. Geophys. Res.Atmos., 120, 4937-4961, doi:10.1002/2014JD023000, 2015.

Schnell, R. C.: Ice Nuclei in Seawater, Fog Water and Marine Air off the Coast of Nova Scotia: Summer 1975, J. Atmos. Sci., 34, 1299-1305, doi:10.1175/15200469(1977)034<1299:INISFW>2.0.CO;2, 1977.

Schnell, R. C.: Airborne ice nucleus measurements around the Hawaiian Islands, J. Geophys. Res., 87, 8886, doi:10.1029/JC087iC11p08886, 1982.

Schnell, R. C. and Vali, G.: Freezing nuclei in marine waters, Tellus, 27, 321-323, doi:10.1111/j.2153-3490.1975.tb01682.x, 1975.

Schnell, R. C. and Vali, G.: Biogenic Ice Nuclei: Part I. Terrestrial and Marine Sources, J. Atmos. Sci., 33, 1554-1564, doi:10.1175/1520-0469(1976)033<1554:BINPIT>2.0.CO;2, 1976.

Sciare, J., Favez, O., Sarda-Estève, R., Oikonomou, K., Cachier, H., and Kazan, V.: Long-term observations of carbonaceous aerosols in the Austral Ocean atmosphere: Evidence of a biogenic marine organic source, J. Geophys. Res., 114, D15302, doi:10.1029/2009JD011998, 2009.

Sesartic, A., Lohmann, U., and Storelvmo, T.: Modelling the impact of fungal spore ice nuclei on clouds and precipitation, Environ. Res. Lett., 8, 014029, doi:10.1088/1748-9326/8/1/014029, 2013.

Spracklen, D. V. and Heald, C. L.: The contribution of fungal spores and bacteria to regional and global aerosol number and ice nucleation immersion freezing rates, Atmos. Chem. Phys., 14, 90519059, doi:10.5194/acp-14-9051-2014, 2014.

Stopelli, E., Conen, F., Morris, C. E., Herrmann, E., Bukowiecki, N., and Alewell, C.: Ice nucleation active particles are efficiently removed by precipitating clouds, Sci. Rep., 5, 16433, doi:10.1038/srep16433, 2015. 
Sullivan, R. C., Miñambres, L., DeMott, P. J., Prenni, A. J., Carrico, C. M., Levin, E. J. T., and Kreidenweis, S. M.: Chemical processing does not always impair heterogeneous ice nucleation of mineral dust particles, Geophys. Res. Lett., 37, L24805, doi:10.1029/2010GL045540, 2010.

Tan, I., Storelvmo, T., and Zelinka, M. D.: Observational constraints on mixed-phase clouds imply higher climate sensitivity, Science, 352, 224-228, doi:10.1126/science.aad5300, 2016.

Tobo, Y., Prenni, A. J., DeMott, P. J., Huffman, J. A., McCluskey, C. S., Tian, G., Pöhlker, C., Pöschl, U., and Kreidenweis, S. M.: Biological aerosol particles as a key determinant of ice nuclei populations in a forest ecosystem, J. Geophys. Res.-Atmos., 118, 10100-10110, doi:10.1002/jgrd.50801, 2013.

Tobo, Y., DeMott, P. J., Hill, T. C. J., Prenni, A. J., SwobodaColberg, N. G., Franc, G. D., and Kreidenweis, S. M.: Organic matter matters for ice nuclei of agricultural soil origin, Atmos. Chem. Phys., 14, 8521-8531, doi:10.5194/acp-14-8521-2014, 2014.

Vali, G.: Repeatability and randomness in heterogeneous freezing nucleation, Atmos. Chem. Phys., 8, 5017-5031, doi:10.5194/acp-8-5017-2008, 2008.

Vali, G. and Snider, J. R.: Time-dependent freezing rate parcel model, Atmos. Chem. Phys., 15, 2071-2079, doi:10.5194/acp15-2071-2015, 2015.

Vali, G., DeMott, P. J., Möhler, O., and Whale, T. F.: Technical Note: A proposal for ice nucleation terminology, Atmos. Chem. Phys., 15, 10263-10270, doi:10.5194/acp-15-10263-2015, 2015.

Vignati, E., Facchini, M., Rinaldi, M., Scannell, C., Ceburnis, D., Sciare, J., Kanakidou, M., Myriokefalitakis, S., Dentener, F., and O'Dowd, C.: Global scale emission and distribution of sea-spray aerosol: Sea-salt and organic enrichment, Atmos. Environ., 44, 670-677, doi:10.1016/j.atmosenv.2009.11.013, 2010.

Wang, X., Sultana, C. M., Trueblood, J., Hill, T. C. J., Malfatti, F., Lee, C., Laskina, O., Moore, K. A., Beall, C. M., McCluskey, C. S., Cornwell, G. C., Zhou, Y., Cox, J. L., Pendergraft, M. A., Santander, M. V., Bertram, T. H., Cappa, C. D., Azam, F., DeMott, P. J., Grassian, V. H., and Prather, K. A.: Microbial Control of Sea Spray Aerosol Composition: A Tale of Two Blooms, ACS Central Science, 1, 124-131, doi:10.1021/acscentsci.5b00148, 2015.

Wang, Y., Liu, X., Hoose, C., and Wang, B.: Different contact angle distributions for heterogeneous ice nucleation in the Community Atmospheric Model version 5, Atmos. Chem. Phys., 14, 1041110430, doi:10.5194/acp-14-10411-2014, 2014.
Westbrook, C. D. and Illingworth, A. J.: Evidence that ice forms primarily in supercooled liquid clouds at temperatures $>-27^{\circ} \mathrm{C}$, Geophys. Res. Lett., 38, 1-4, doi:10.1029/2011GL048021, 2011.

Westbrook, C. D. and Illingworth, A. J.: The formation of ice in a long-lived supercooled layer cloud, Q. J. Roy. Meteorol. Soc., 139, 2209-2221, doi:10.1002/qj.2096, 2013.

Wex, H., DeMott, P. J., Tobo, Y., Hartmann, S., Rösch, M., Clauss, T., Tomsche, L., Niedermeier, D., and Stratmann, F.: Kaolinite particles as ice nuclei: learning from the use of different kaolinite samples and different coatings, Atmos. Chem. Phys., 14, 55295546, doi:10.5194/acp-14-5529-2014, 2014.

Whale, T. F., Murray, B. J., O’Sullivan, D., Wilson, T. W., Umo, N. S., Baustian, K. J., Atkinson, J. D., Workneh, D. A., and Morris, G. J.: A technique for quantifying heterogeneous ice nucleation in microlitre supercooled water droplets, Atmos. Meas. Tech., 8, 2437-2447, doi:10.5194/amt-8-2437-2015, 2015.

Wilson, T. W., Ladino, L. A., Alpert, P. A., Breckels, M. N., Brooks, I. M., Browse, J., Burrows, S. M., Carslaw, K. S., Huffman, J. A., Judd, C., Kilthau, W. P., Mason, R. H., McFiggans, G., Miller, L. A., Nájera, J. J., Polishchuk, E., Rae, S., Schiller, C. L., Si, M., Vergara Temprado, J., Whale, T. F., Wong, J. P. S., Wurl, O., Yakobi-Hancock, J. D., Abbatt, J. P. D., Aller, J. Y., Bertram, A. K., Knopf, D. A., and Murray, B. J.: A marine biogenic source of atmospheric ice-nucleating particles, Nature, 525, 234-238, doi:10.1038/nature14986, 2015.

Yin, J., Wang, D., and Zhai, G.: An evaluation of ice nuclei characteristics from the long-term measurement data over North China, Asia-Pac. J. Atmos. Sci., 48, 197-204, doi:10.1007/s13143-0120020-8, 2012.

Young, K. C.: A Numerical Simulation of Wintertime, Orographic Precipitation: Part I, Description of Model Microphysics and Numerical Techniques, J. Atmos. Sci., 31, 1735-1748, 1974.

Zeng, X., Tao, W.-K., Zhang, M., Hou, A. Y., Xie, S., Lang, S., Li, X., Starr, D. O., Li, X., and Simpson, J.: An indirect effect of ice nuclei on atmospheric radiation, J. Atmos. Sci., 66, 41-61, doi:10.1175/2008JAS2778.1, 2009.

Zolles, T., Burkart, J., Häusler, T., Pummer, B., Hitzenberger, R., and Grothe, H.: Identification of ice nucleation active sites on feldspar dust particles, J. Phys. Chem. A, 119, 2692-2700, doi:10.1021/jp509839x, 2015. 